\title{
Structural Comparison of Copper(II) Thiocyanate Pyridine
}

\section{Complexes}

Joseph V. Handy, Gerardo Ayala, and Robert D. Pike*.

Department of Chemistry, College of William and Mary, Williamsburg, VA 23187.

Corresponding Author: $\quad$ Robert D. Pike

Department of Chemistry

College of William and Mary

Williamsburg, VA 23187-8795.

telephone: 757-221-2555

FAX: 757-221-2715

email: rdpike@wm.edu

Keywords: Copper, thiocyanate, Jahn-Teller, metal-organic network, X-ray structure, polymorphism 


\begin{abstract}
:
Copper(II) thiocyanate forms a series of closely related complexes when reacted with substituted pyridines (XPy) in methanol. Although these compounds are nominally square planar trans$\left[\mathrm{Cu}(\mathrm{NCS})_{2}(\mathrm{XPy})_{2}\right]$, most show N,S-thiocyanate bridging via long $\mathrm{Cu}-\mathrm{S}$ bonds of $\geq 2.7 \AA$, The resulting JahnTeller (J-T) distorted octahedra form edge-sharing chains. However, these units can also form sheets or small oligomers. For some 2- or 3-substituted pyridines, isolated square planar trans-[Cu(NCS $\left.)_{2}(\mathrm{XPy})_{2}\right], \mathrm{J}$ T distorted octahedral trans-[Cu(NCS $\left.)_{2}(\mathrm{XPy})_{2}(\mathrm{MeOH})_{2}\right]$, or square pyramid trans-[Cu(NCS)$\left.)_{2}(\mathrm{XPy})_{2}(\mathrm{MeOH})\right]$ were isolated. Polymorphism and/or solvento isomers appear to be common, being identified for five of 21 ligands studied. Use of 2- $\mathrm{NH}_{2} \mathrm{Py}$ produces methoxy-bridged dimers $\left[\mathrm{Cu}_{2}(\mathrm{NCS})_{2}\left(2-\mathrm{NH}_{2} \mathrm{Py}\right)_{2}(\mu-\mathrm{OMe})_{2}\right]$ that are further linked via bridging thiocyanate to form a sheet structure. Unusual aryl bromide metal chelation is noted in the mixed ligand complex trans-[Cu(NCS)$\left.)_{2}(2-B r P y)(3-B r P y)\right]$. When $L L=4,4^{\prime}-$ bipyridyl (Bpy) or pyrazine (Pyz) is used, bridging by both the organic and thiocyanate ligands produces sheet networks, trans-[Cu(NCS) $\left.)_{2}(\mathrm{LL})\right]$.
\end{abstract}

\title{
Introduction:
}

Metal-organic network formation is a topic of great interest, showing potential in applications such as molecular separation [1], sensing [2], luminescent materials [3], and gas adsorption [4]. Maintaining network pore structure can depend on the use of coordinating anions which constitute part of the lattice itself, rather than non-coordinating ions that tend to fill the network pores. Anions that can bridge metal centers particularly enhance network formation. The thiocyanate ion $\left(\mathrm{SCN}^{-}\right)$is just such an anionic ligand, acting in a variety of bonding modes, including various bridging modes, see Scheme 1 
[5],[6]. Moreover, thiocyanate is non-innocent in its bonding, which can occur through either $\mathrm{N}$ or $\mathrm{S}$. Finally, although thiocyanate is typically regarded as a soft base, there is a degree of hard/soft distinction that affects its bonding. The nitrogen atom in $\mathrm{SCN}^{-}$tends to be a harder donor than sulfur. The overall soft nature of thiocyanate is implicated in its tendency to favor copper(I) over copper(II) [7]. Thus, although the black copper(II) thiocyanate is relatively stable as a solid, solutions of $\mathrm{Cu}(\mathrm{NCS})_{2}$ are unstable with respect to copper(I) thiocyanate formation:

$$
\mathrm{Cu}(\mathrm{NCS})_{2} \rightarrow \mathrm{CuSCN}+1 / 2(\mathrm{SCN})_{2}
$$

Byproduct thiocyanogen, $(\mathrm{SCN})_{2}$, is a solid, but in aqueous solution it is known to decompose with evolution of HCN gas:

$$
3(\mathrm{SCN})_{2}+4 \mathrm{H}_{2} \mathrm{O} \rightarrow 5 \mathrm{HNCS}+\mathrm{H}_{2} \mathrm{SO}_{4}+\mathrm{HCN}
$$

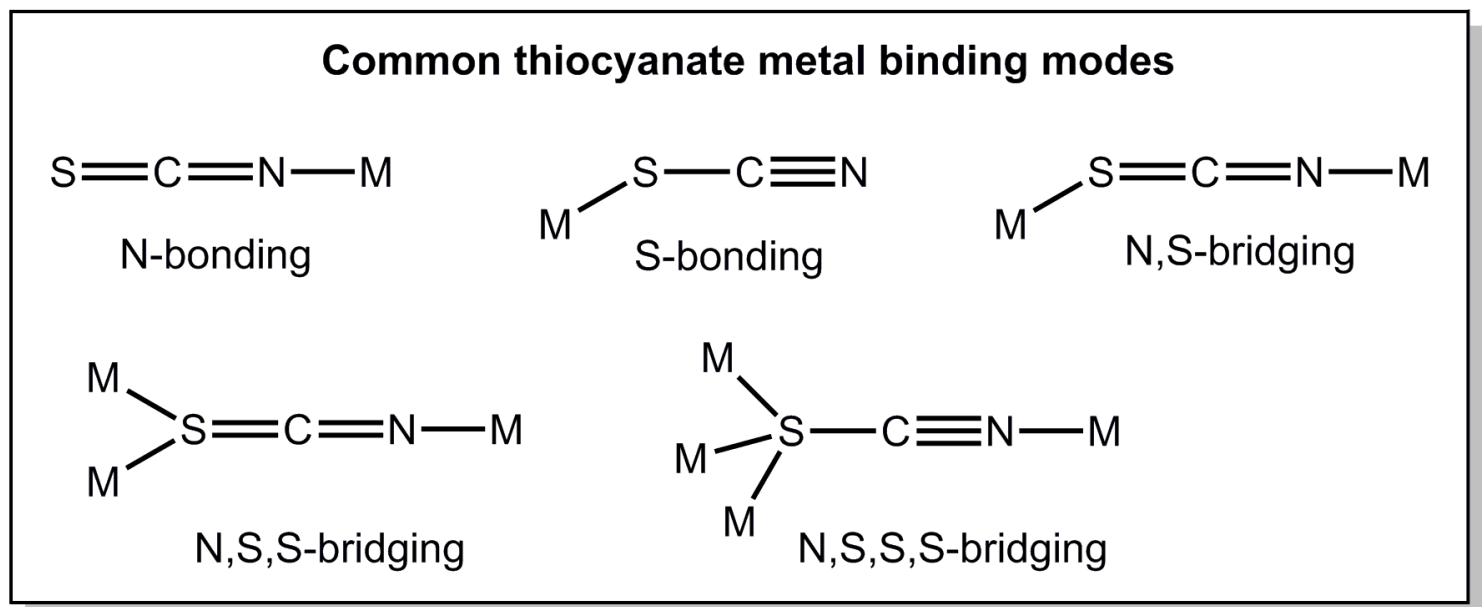

Scheme 1. Resonance forms and common metal bonding modes of thiocyanate. 
In the present study, we set out to evaluate the bonding modes and network formation in the copper(II) complexes of thiocyanate in the presence of substituted pyridine ligands (XPy). We chose methanol as solvent because it solubilizes the reactants and products, and as a hard donor solvent would presumably help stabilize $\mathrm{Cu}(\mathrm{II})$. The structural questions that interested us were:

1. What would be the favored metal coordination number?

2. Would the coordination geometry be cis or trans?

3. Would monodentate $\mathrm{S}$ or $\mathrm{N}$ thiocyanate-metal linkage, or bridging linkage be favored?

4. Would consistent Jahn-Teller (J-T) distortion be evident?

5. Would the tendency of thiocyanate to bridge metal centers consistently result in network formation?

6. Would $\mathrm{MeOH}$ coordination be observed?

7. Could the relative stability of $\mathrm{Cu}(\mathrm{II})$ vs. $\mathrm{Cu}(\mathrm{I})$ thiocyanate be assessed in $\mathrm{MeOH}$ ?

Several trans-[Cu(NCS $\left.)_{2}(\mathrm{XPy})_{2}\right]$ structures already appear in the literature [8]-[21]. These complexes will be discussed below in context with those prepared herein. Nevertheless, in order to set the stage several relevant structures are shown in Figure 1. Examining these compounds, it appears that thiocyanate nitrogen coordination to $\mathrm{Cu}(\mathrm{II})$ and trans geometry are the rule. Relatively long $\mathrm{Cu}-\mathrm{S}$ bonds are in evidence, resulting in networks in most cases. Based on Bondi's calculations of van der Waals radii, in the discussions below we will regard a Cu“'S distance of $>3.2 \AA$ as being non-bonding [22]. In the relatively simple Py complex (1) $\mathbf{1 b}$, see Table 1 below for a full list of complexes considered), Cu-S bonding (3.042 $\AA$ ) produces chains of edge-sharing octahedra [8]. This results in the monomer units linking together into chains via eight-membered $\mathrm{Cu}_{2}(\mathrm{NCS})_{2}$ rings that share $\mathrm{Cu}$ centers. A second trans$\left[\mathrm{Cu}(\mathrm{NCS})_{2}(\mathrm{Py})_{2}\right]$ polymorph (1a) with $\mathrm{Cu}-\mathrm{S}=3.045$ and $3.085 \AA$ is also known [9]. A significant difference between the polymorphs is that $\mathbf{1 a}$ shows a face-to-face and several edge-to-face $\pi$-stacking interactions between the rings (see below for discussion of $\pi$-stacking interactions), while $\mathbf{1 b}$ shows no 
inter-chain interactions. In the 3-acetylpyridine (3-AcPy) complex (12b), these putative chains are broken into dimers ( $\mathrm{Cu}-\mathrm{S}=2.863 \AA$ ) [10]. The dimers do not link together via Cu“'S (4.119 $)$ ). Instead, they are linked by face-to-face $\pi$-stacking. In the 4- $\mathrm{NH}_{2} \mathrm{COPy}$ complex (24), the single unique $\mathrm{Cu}-\mathrm{S}$ bond is relatively short (2.9498 $\AA$ ) [11]. Instead of $\mathrm{Cu}_{2}(\mathrm{NCS})_{2}$ units, the herringbone 24 network is based upon sheets of tiled $\mathrm{Cu}_{4}(\mathrm{NCS})_{4}$ macrocycles. In the $4-\mathrm{NH}_{2}$ Py complex (17), one set of NCS ligands is pendant, while the other set bridges to produce chains [12],[13]. Thus, with one clearly bonding and one nonbonding Cu-S (2.867 and $3.508 \AA)$, the metal center is best described as square pyramidal, and the resulting chain as square-wave. Finally, the $3-(2-\mathrm{MeOPhCH}=\mathrm{NPy})$ complex (27) is a J-T distorted octahedron with two slightly elongated $\mathrm{Cu}-\mathrm{O}$ bonds $(2.430 \AA$ ) to methanol ligands [14]. A search of the Cambridge Crystallographic Database reveals an average $\mathrm{Cu}-\mathrm{O}$ bond length of 2.29(3) $\AA$ [23]. In the new results described herein, we will see structures related to these five types, plus some motifs not yet encountered.

Figure 1. X-ray crystal structures: trans-[Cu(NCS $\left.)_{2}(\mathrm{Py})_{2}\right]$ 1b, trans-[Cu(NCS $\left.)_{2}(3-\mathrm{AcPy})_{2}\right]$ 12b, trans$\left[\mathrm{Cu}(\mathrm{NCS})_{2}\left(4-\mathrm{NH}_{2} \mathrm{COPy}\right)_{2}\right] \quad \mathbf{2 4}, \quad$ trans- $\left[\mathrm{Cu}(\mathrm{NCS})_{2}\left(4-\mathrm{NH}_{2} \mathrm{Py}\right)_{2}\right] \quad \mathbf{1 7}, \quad$ trans- $\left[\mathrm{Cu}(\mathrm{NCS})_{2}(3-(2-\right.$ $\left.\mathrm{HOPhCH}=\mathrm{NPy}))_{2}(\mathrm{MeOH})_{2}\right] 2$ 27. Color scheme for all X-ray figures: orange $=\mathrm{Cu}$, yellow $=\mathrm{S}$, grey $=\mathrm{C}$, blue $=$ $\mathrm{N}$, red $=\mathrm{O}$, yellow-green $=\mathrm{F}$, green $=\mathrm{Cl}$, dark red $=\mathrm{Br}$. Copper thiocyanate atoms shown as ball and stick and other ligands as wireframe. Hydrogen atoms omitted. 

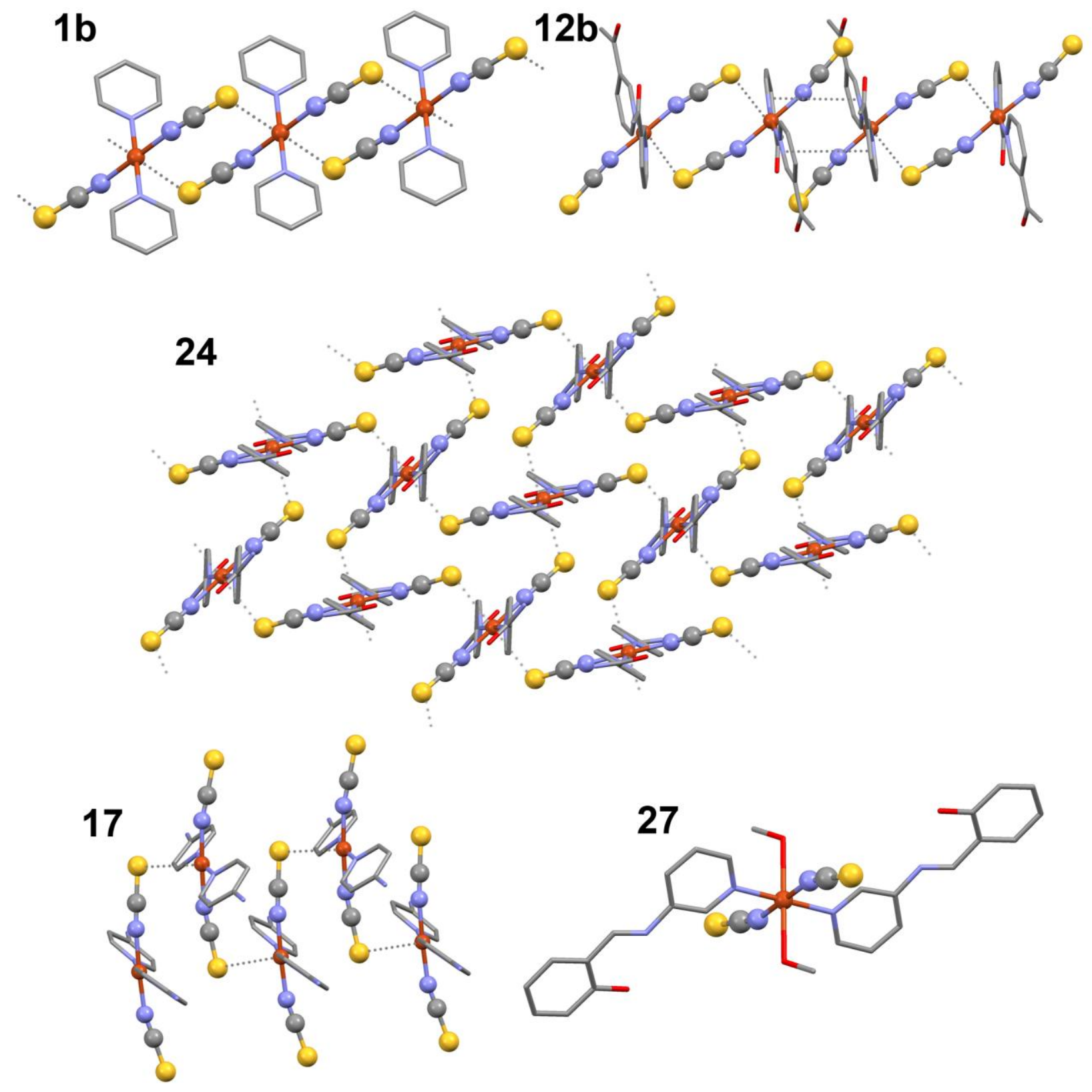

Experimental:

General: 
All reagents were obtained from Acros or Aldrich Chemicals and were used as received. Copper analysis were carried out by atomic absorption spectroscopy as previously described [24]. CHN Analyses were carried out by Atlantic Microlab, Norcross GA. Infrared spectra were carried out in ATR mode using a Shimadzu IRTracer-100.

CAUTION! Reactions described herein should be carried out at reduced temperature in a fume hood because formation of thiocyanogen in solution can produce traces of $\mathrm{HCN}$ gas [7].

General Procedure for producing crystals of trans-[Cu(NCS $\left.)_{2}(\mathrm{XPy})_{2}(\mathrm{MeOH})_{x}\right] \cdot \mathrm{Cu}\left(\mathrm{NO}_{3}\right)_{2} \cdot 2 \cdot 5 \mathrm{H}_{2} \mathrm{O}$ $(0.10 \mathrm{~g}, 0.43 \mathrm{mmol})$ was dissolved in $15 \mathrm{~mL}$ of $\mathrm{MeOH}$ at $0{ }^{\circ} \mathrm{C}$. Solid $\mathrm{NH}_{4} \mathrm{SCN}(0.065 \mathrm{~g}, 0.86 \mathrm{mmol})$ was added to the solution, resulting in a green/brown solution of $\mathrm{Cu}(\mathrm{SCN})_{2} \bullet x \mathrm{MeOH}$. Excess XPy ligand (about 3 drops) was added, forming a green solution. The solution was cooled in a freezer until crystals formed. The supernatant was poured off and the crystals washed with ethyl ether and then air dried. In all cases the crystals in each batch were highly homogeneous in appearance. In the case of Bpy and Pyz ligands, insoluble products are produced. In order to form crystals with these ligands a $\mathrm{MeOH}$ solution of $\mathrm{Cu}\left(\mathrm{NO}_{3}\right)_{2} \bullet 2.5 \mathrm{H}_{2} \mathrm{O}$ and $\mathrm{NH}_{4} \mathrm{SCN}$ prepared as described above was layered with an equal volume of $\mathrm{MeOH}$ solution containing $0.22 \mathrm{mmol}$ of ligand. Product yields and $\mathrm{Cu}$ analysis results are listed in Table 1.

X-ray crystallography.

Crystals were mounted on glass fibers. All measurements were made using graphitemonochromated $\mathrm{Cu} \mathrm{K} \alpha$ radiation on a Bruker-AXS three-circle diffractometer, equipped with an Apex II CCD detector. Initial space group determination was based on a matrix consisting of 120 frames. The data were reduced using SAINT+ [25], and empirical absorption correction applied using SADABS [26].

Structures were solved using intrinsic phasing. Least-squares refinement for all structures was carried out on $F^{2}$. The non-hydrogen atoms were refined anisotropically. Hydrogen atoms were placed in 
riding positions and refined isotropically. Structure solution, refinement, and the calculation of derived results were performed using the SHELXTL package of computer programs [27] and ShelXle [28]. Details of the X-ray experiments and crystal data are summarized in Table 2. Selected bond lengths and bond angles are given in Table 3.

\section{Results:}

While a number of pyridine complexes of copper(II) thiocyanate have been reported [8]-[21], no systematic structural study and analysis has been carried out on the series. The complexes prepared and studied herein were easily synthesized as large green, blue, or black crystals by combining copper(II) nitrate, ammonium thiocyanate, and substituted pyridine in methanol at $0{ }^{\circ} \mathrm{C}$.

$$
\begin{gathered}
\mathrm{Cu}\left(\mathrm{NO}_{3}\right)_{2} \cdot 2.5 \mathrm{H}_{2} \mathrm{O}+2 \mathrm{NH}_{4} \mathrm{SCN}+2 \mathrm{XPy}+x \mathrm{MeOH} \\
\rightarrow \text { trans- }\left[\mathrm{Cu}(\mathrm{NCS})_{2}(\mathrm{XPy})_{2}(\mathrm{MeOH})_{x}\right]+2 \mathrm{NH}_{4} \mathrm{NO}_{3}+2.5 \mathrm{H}_{2} \mathrm{O}
\end{gathered}
$$

Continuous cooling of the green/brown reaction solution produced crystals for most of the substituted pyridines tried (see Table 1). In some cases formation of crystals occurred within minutes, while in other instances storage in a freezer overnight or longer was required. Several ligands failed to result in crystal formation. These included 2-MeOPy, 2-ClPy, 2-BrPy, 3-IPy, 3- $\mathrm{NH}_{2} \mathrm{Py}$, and 4-PhPy, all of which produced only powders, and 3-HOPy and 4-HOPy, neither of which produced solids under the conditions used, perhaps due to failure of the pyridine to coordinate.

The majority of the crystalline products were stable when isolated. Nevertheless, for three of the compounds (2a, 12a, and 14, see Table 1 ) the crystals evidenced the presence of solvent incorporation, becoming opaque after isolation from suspension. These methanol-containing products and the methoxide-containing product $\mathbf{1 6}$ also tended to be bluish in color. The former products evidenced slow loss of methanol, as indicated by clouding of crystals over a matter of hours to days. 
The preparation of this compound series afforded an opportunity to compare IR spectra. While it is generally recognized that $v_{\mathrm{CN}}$ show lower frequency values and $v_{\mathrm{SC}}$ exhibit higher values for $\mathrm{N}$-bound thiocyanate complexes, these rules must be applied with caution because many other factors can exert influence on the positions of these bands [6],[29]. All of the $\mathrm{Cu}(\mathrm{II})$ compounds prepared herein may be considered to bond to the metal through $\mathrm{N}$, with additional weak S-bonding occurring in most cases (see below). IR spectra of complexes prepared herein and the free ligands are found in the Supporting Information. Notable IR bands are listed in Table 4. Single $v_{\mathrm{CN}}$ bands were observed in the range 2073$2097 \mathrm{~cm}^{-1}$ for all but five of the 21 complexes prepared. For the complexes of 3-MeOPy (10), 3-AcPy (12a), 4- $\mathrm{NH}_{2} \mathrm{Py}$ (17), Pdz (20), and Pyz (22) pairs of bands in the ranges of $2058-2073 \mathrm{~cm}^{-1}$ and $2104-$ $2129 \mathrm{~cm}^{-1}$ were found. Thus, relatively high frequency $\mathrm{C} \equiv \mathrm{N}$ bands were noted for all of the complexes studied. Such bands are more consistent with either S-bonding or N,S-bridging behavior (bands expected near $2100 \mathrm{~cm}^{-1}$ ) than with $\mathrm{N}$-bound behavior (bands expected near $2050 \mathrm{~cm}^{-1}$ ) [6],[29]. The $v_{\mathrm{Sc}}$ bands are challenging to identify because they are not particularly intense and tend to overlap with aromatic resonances. Comparison of complex and free XPy bands allowed for tentative identification of the $v_{\mathrm{SC}}$ bands in the range $760-867 \mathrm{~cm}^{-1}$. This range is in good agreement with that recognized for $\mathrm{N}$-bonded $\left(760-860 \mathrm{~cm}^{-1}\right)$ rather than S-bonded $\left(690-720 \mathrm{~cm}^{-1}\right)$ thiocyanate complexes.

X-ray structures of 20 new compounds were solved as part of this study. Selected bond lengths and angles for new and known compounds are compiled in Table 3. In addition to the figures shown below, thermal ellipsoid drawings and packing diagrams can be found in the Supporting Information. Before we consider structural distinctions amongst the various complexes, let us first note some of their consistent characteristics. In all the complexes, the pairs of thiocyanate ligands (and pairs of pyridines) are disposed trans to one another. Furthermore, in all cases the $\mathrm{Cu}-\mathrm{N}_{\mathrm{Py}}(1.98-2.08 \AA$ ) exceeds that of $\mathrm{Cu}-\mathrm{N}_{\mathrm{CS}}(1.92-1.97 \AA$, ignoring a single disordered residue in compound 11). Irrespective of complex geometry, which spans a range between square planar, distorted octahedral, and square pyramid, all 
the cis $\mathrm{N}-\mathrm{Cu}-\mathrm{N}$ angles were nearly $90^{\circ}$, varying from this value by no more than $4^{\circ}$, and usually less than $1^{\circ}$. As expected, the thiocyanate $\mathrm{N}-\mathrm{C}-\mathrm{S}$ bond angles were always nearly linear, deviating from $180^{\circ}$ by $6.5^{\circ}$ at most, and again usually showing deviations of less than $1^{\circ}$. The $\mathrm{Cu}-\mathrm{N}-\mathrm{C}$ bond angles tended toward linearity, but showed much wider variation, ranging between $154^{\circ}$ and $179^{\circ}$. Two kinds of $\pi$ stacking are noted in the various compounds described below. Face-to-face stacking is commonly noted when the pyridine rings are arranged in parallel fashion, while canting of adjacent rings tends to result in edge-to-face (T-shaped) $\pi$-stacking [30]. Centroid'“centroid cutoff values of 4.0 and $5.7 \AA$ were used in identifying these interactions.

The crystal structures of trans-[Cu(NCS $\left.)_{2}(\mathrm{XPy})_{2}\right]$ can be divided into the seven categories listed in Table 5. We will consider the structures belonging to each category, beginning with " $\mathrm{D}_{4 \mathrm{~h}}$ chains." These complexes consist of nearly isolated square planar $\left(\mathrm{D}_{4 h}\right)$ trans-[Cu(NCS $\left.)_{2}(\mathrm{XPy})_{2}\right]$ molecules. However, because $\mathrm{Cu}(\mathrm{II})$ favors the formation of J-T distorted octahedra, in this largest category of $\mathrm{CU}(\mathrm{II})$ thiocyanate pyridine complexes, long intermolecular $\mathrm{Cu}-\mathrm{S}$ bonds are formed between the 4-coordinate monomers. These connections transform the otherwise isolated square planes to tetragonally J-T distorted edge-sharing octahedra that form chains. The $\mathrm{Cu}-\mathrm{S}$ bonds in these complexes range between 2.7-3.2 A. A search of the Cambridge Crystallographic Database reveals that the average Cu-S bond length is $2.32(12) \AA$, with an overall range of $1.90-3.42 \AA$ [23]. In fact, all of the compounds having Cu-S interactions considered in this study lie near the top of this range (2.69-3.20 $\AA$ ). In addition, as we shall see below, even longer $\mathrm{Cu}$ '.' $\mathrm{S}$ interactions exist in complexes described herein as " $\mathrm{D}_{4 \mathrm{~h}}$ monomers." Thus, there is really no simple cutoff for $\mathrm{Cu}-\mathrm{S}$ bonding.

Ten complexes described as $\mathrm{D}_{4 \mathrm{~h}}$ chains are listed in Table 4. These incorporate the ligands Py (two polymorphs, 1a and 1b) [8],[9], 3-FPy (5), 3-ClPy (6), 4-BrPy (9) [16],[17], 4-AcPy (13a), 4-NCPy (two polymorphs, 15a and 15b) [12], 4-PhCOPy (26) [20], and pyridazine (Pdz, 20). Known Py complex 1a was 
identified as the product formed in the present study, while polymorph $\mathbf{1 b}$ was not observed. Of course, identification of $\mathbf{1 a}$ does not rule out the possible presence of $\mathbf{1 b}$ in the Py product. (The same is true of other "missing" polymorphs and solvates in the various products prepared herein.) Five new $\mathrm{D}_{4 \mathrm{~h}}$ chain structures (5, 6, 13a, 15a, and 20) were identified and are depicted in Figure 2. All of the new compounds are structurally similar. In the structure of $\mathbf{5}$ the fluorine atom is disordered between the two meta positions. Interestingly, in the crystallization mixture using 4-AcPy two polymorphs were identified. One of these was a $D_{4 h}$ chain (13a), while the other was a $D_{4 h}$ network (13b, see below). The 4-NCPy complex also shows polymorphism, with the complex isolated herein (15a) proving to be a polymorph of the known species $\mathbf{1 5 b}$. Pi-stacking is very common amongst the $D_{4 h}$ chain complexes. Complexes $\mathbf{1 b}, \mathbf{5}, \mathbf{6}$, and $\mathbf{2 0}$ show face-to-face inter-chain $\pi$-stacking of pyridine rings (centroid"'centroid $=3.813 \AA$ for $1 \mathbf{b}, 3.702 \AA$ for $5,3.387 \AA$ for 6 , and $3.578 \AA$ for 20 ). Both $15 a$ and $15 b$ show canting of the pyridine rings, resulting in edge-to-face $\pi$-stacking. Compound 5 also shows a very close edge-to-face $\pi$ stack in which the "edge' atom is shared between disordered H/F positions. Compound 13a shows an interaction between an acetyl methyl and pyridine $\left(\mathrm{C}_{\mathrm{Me}}\right.$ - centroid $\left.=3.785 \AA\right)$. The use of the potentially bidentate pyridazine failed to result in Pdz bridging. Unlike 4,4'-bipyridyl (Bpy) and pyrazine (Pyz), the Pdz ligands in $\mathbf{2 0}$ proved to be strictly monodentate. This complex also showed edge-to-face $\pi$-stacking.

Figure 2. X-ray structures of new $\mathrm{D}_{4 \mathrm{~h}}$ chain complexes: trans- $\left[\mathrm{Cu}(\mathrm{NCS})_{2}(3-\mathrm{FPy})_{2}\right] \mathbf{5}$, trans- $\left[\mathrm{Cu}(\mathrm{NCS})_{2}(3-\right.$ $\left.\mathrm{ClPy})_{2}\right]$ 6, trans-[Cu(NCS $\left.)_{2}(4-\mathrm{AcPy})_{2}\right]$ 13a, trans-[Cu(NCS $\left.)_{2}(4-\mathrm{NCPy})_{2}\right]$ 15a, and trans-[Cu(NCS $\left.)_{2}(\mathrm{Pdz})_{2}\right] 20$. See Figure 1 for atom color key. For Pdz complex 20, the ring nitrogen is shown adjacent to the sulfur atom. 

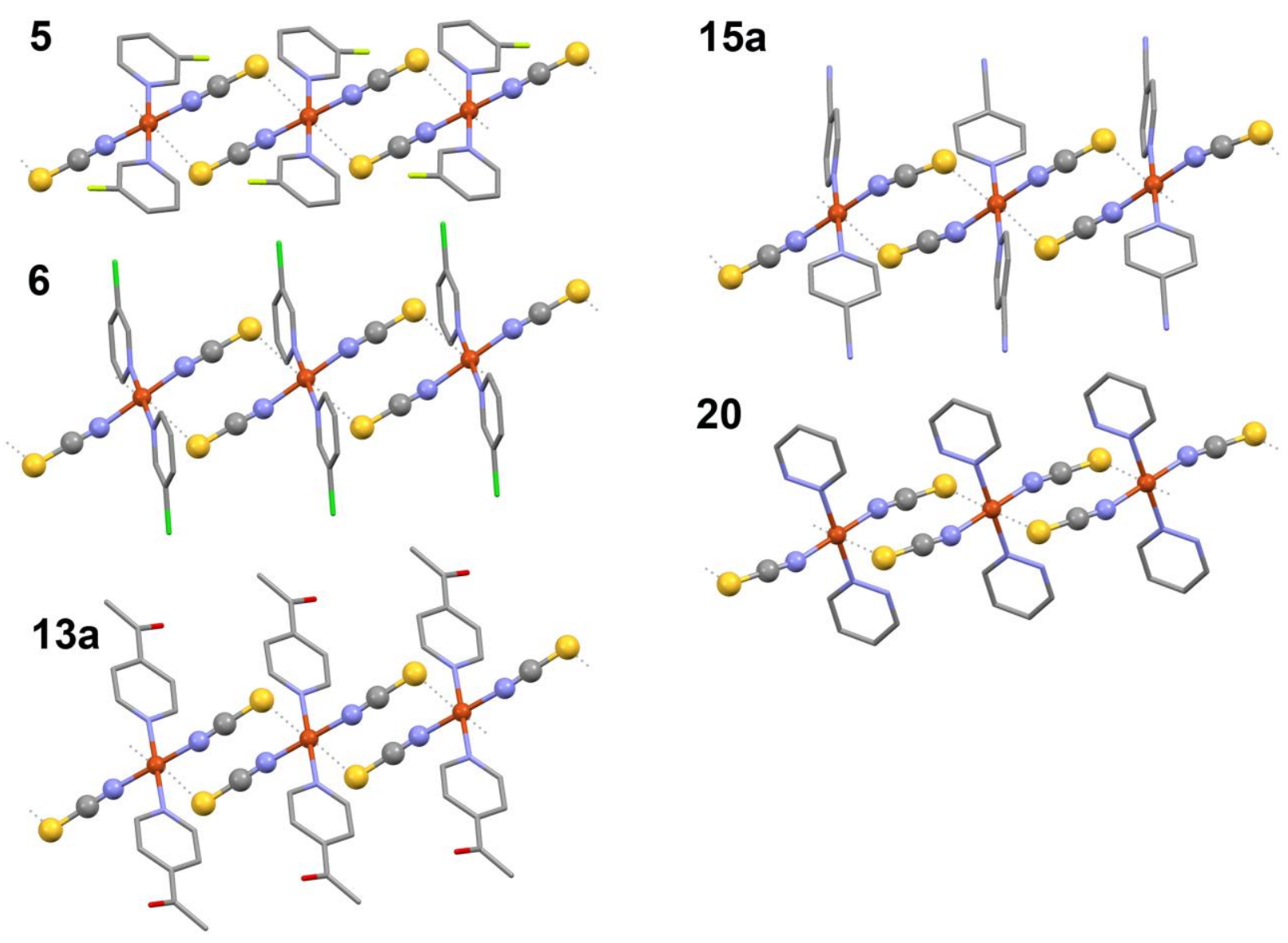

The five structures described as $D_{4 h}$ networks in Table 5 are closely related to the $D_{4 h}$ chains. As with the former group, these complexes show long $\mathrm{Cu}-\mathrm{S}$ bonds that link the monomers. However, whereas the $D_{4 h}$ chains are constructed from linking of monomers pairwise via $\mathrm{Cu}_{2}(N C S)_{2}$ rings, the $D_{4 h}$ networks exhibit branch points at which pairs of thiocyanate ligands fail to form a bimetallic ring. One example of this behavior that was noted above (see Figure 1) is the 4- $\mathrm{NH}_{2} \mathrm{COPy}$ complex 24 [11]. The formation of 2-D sheets from tiled $\mathrm{Cu}_{4}(\mathrm{NCS})_{4}$ in this species is unique. Another network example from the literature is the 2-MePy complex, $\mathbf{2 b}$ [15]. This complex was not formed in the current study when 2MePy was used. Instead, complex $\mathbf{2 a}$ containing $\mathrm{MeOH}$ was isolated (see below). Although the literature structure of $\mathbf{2} \mathbf{b}$ is of fairly low quality, it consists of trimers of edge-sharing octahedra which are essentially fragments of the $D_{4 h}$ chains. The trimers are half-independent. In addition, an independent square planar $\mathrm{Cu}$ monomer is present. It weakly bonds ( $\mathrm{Cu}$ '. $S=3.263 \AA$ ) to a terminal sulfur on the 
trimer. Remarkably, this $\mathrm{Cu}$ center lacks a sixth ligand. Considering this as five-coordinate square pyramid trans-[Cu(NCS $\left.)_{2}(\mathrm{XPy})_{2} \mathrm{~L}\right]$, it joins only one other such center, which is reported in the current study. Interestingly, this latter complex (2a, see below) also contains the 2-MePy ligand.

The literature structure of complex 4 was also of relatively low quality [18]. Because 4 was formed in the reaction of $4-\mathrm{MePy}$ here, its structure was re-determined. The resulting structure crystallized as a racemic twin and is shown, along with those of the new complexes $\mathbf{1 1}$ and $\mathbf{1 3 b}$ in Figure 3. As is the case with $\mathbf{2 b}$, complex $\mathbf{4}$ consists of edge-sharing trimers. However, in this case there are three fully independent $\mathrm{Cu}$ atoms in the trimer unit. The trimers in $\mathbf{4}$ connect to one another at branch points to form a zigzag pattern, rather than terminating at an independent square planar trans$\left[\mathrm{Cu}(\mathrm{SCN})_{2}(\mathrm{MePy})_{2}\right]$ unit, as they do in $\mathbf{2 b}$. Interestingly, the $\mathrm{Cu}-\mathrm{S}$ connections between the trimers (2.9864(11) and 3.1475(11) $\AA$ ) are on average longer than those within the trimers $(\mathrm{Cu}-\mathrm{S}=2.9098(11)$, 2.9137(11), 2.9413(11), and 3.0971(11) ^). The canting of the six independent pyridine rings produces many edge-to-face $\pi$-stacking interactions in $\mathbf{4}$.

Figure 3. X-ray structures of new $\mathrm{D}_{4 \mathrm{~h}}$ network complexes: trans-[Cu(NCS $\left.)_{2}(4-\mathrm{MePy})_{2}\right]$ 4, trans$\left[\mathrm{Cu}(\mathrm{NCS})_{2}(4-\mathrm{MeOPy})_{2}\right]$ 11, and trans-[Cu(NCS $\left.)_{2}(4-\mathrm{AcPy})_{2}\right]$ 13b. See Figure 1 for atom color key. 


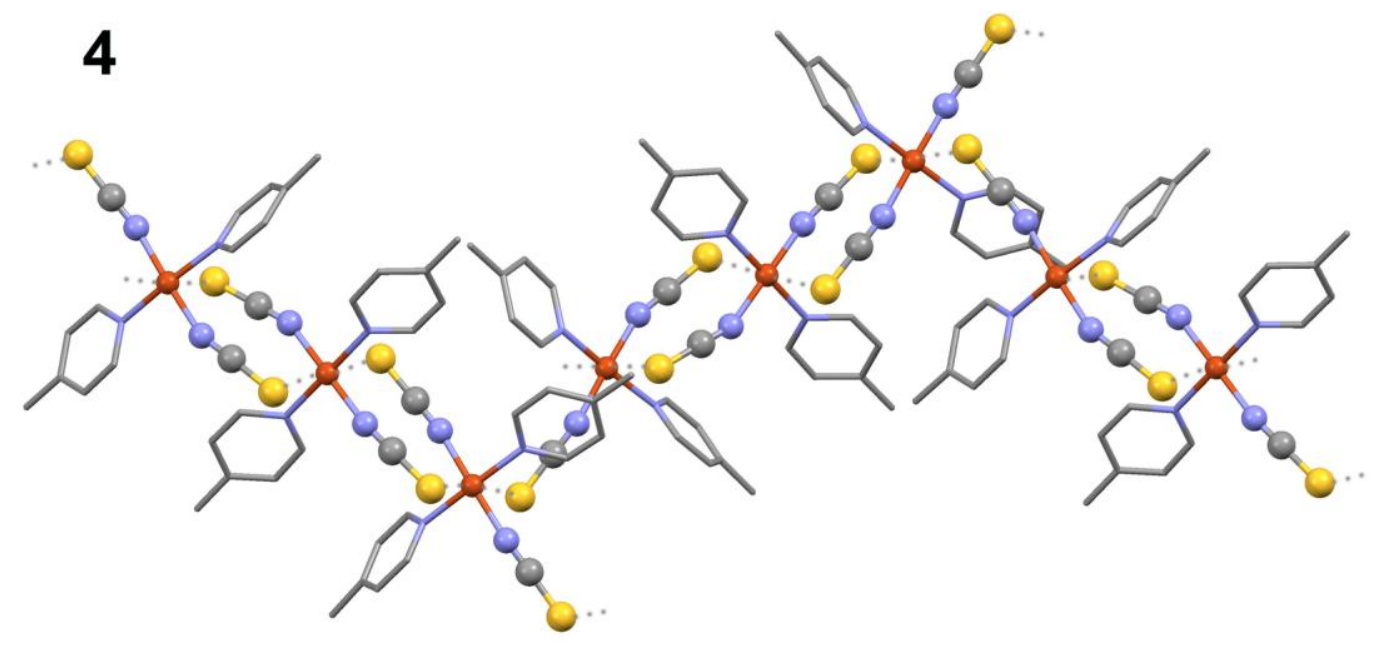

11
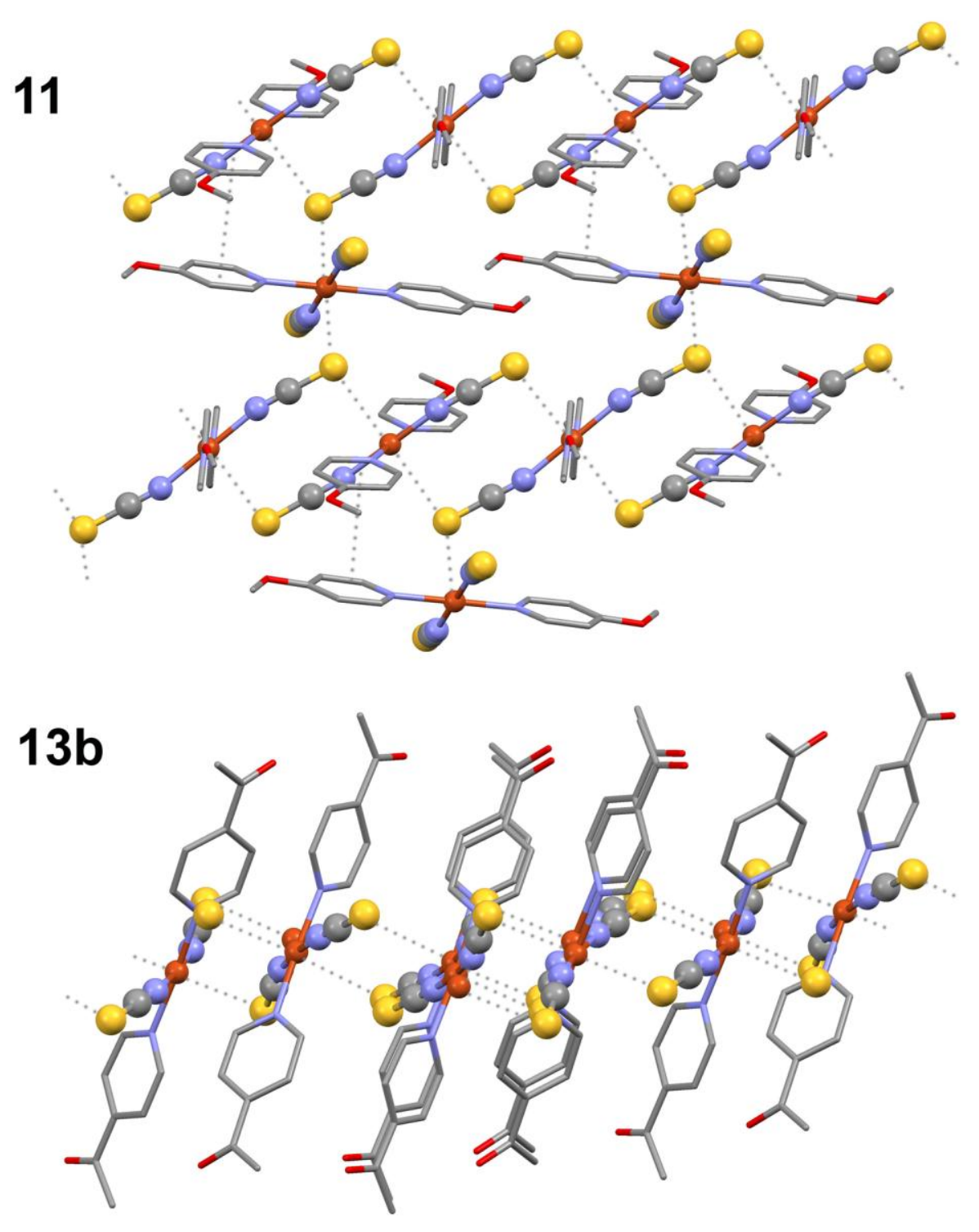
4-Methoxypyridine complex $\mathbf{1 1}$ is constructed from three half-independent $\mathrm{Cu}$ units. It shows significant disorder, having two positions each for one of the thiocyanate ligands and one of the 4MeOPy ligands. Nevertheless, the complex revealed an interesting and unique arrangement (Figure 3). Rows of $D_{4 h}$ chains are separated by nearly isolated $D_{4 h}$ units. These latter monomers show weak $C u-S$ (3.1051(4) $\AA$ ) connections to the chains lying above and below them. Only half of the Cu atoms in the chains connect to the monomers. The thiocyanate units on the monomer are truly terminal, bonding only through N. Moreover, this complex represents the only case amongst the various trans$\left[\mathrm{Cu}(\mathrm{NCS})_{2}(\mathrm{XPy})_{2}\right]$ complexes in which a single sulfur atom bonds to more than one copper atom. In addition, a face-to-face $\pi$-stacking arrangement is noted between a chain and a monomer pyridine (centroid"'centroid $=3.688 \AA$ ), and an edge-to-face $\pi$-stacking is present along the chain. A second 4AcPy polymorph, compound $\mathbf{1 3 b}$, is shown in Figure 3. It is also structurally unique in this study. The network can be described as consisting of a series of '“'CuNCS"' helices, in which the prototypical dimers are opened up $(\mathrm{Cu}-\mathrm{S}=2.8258(5) \AA ̊ \AA)$. The second set of thiocyanate units projects out from the helix, linking with adjacent helices to form $\mathrm{Cu}_{2}(\mathrm{NCS})_{2}$ dimers, thus knitting them together $(\mathrm{Cu}-\mathrm{S}=3.0460(5) \AA)$ into sheets. Compound $\mathbf{1 3 b}$ shows unusually close $\mathrm{H}_{\text {pyridine }} \mathrm{O}^{\mathrm{O}} \mathrm{O}_{\text {acetyl }}$ and $\mathrm{H}_{\text {acetyl }} \cdots \mathrm{O}_{\text {acetyl }}$ interactions between adjacent sheets $(\mathrm{H} 6 \cdots \mathrm{O} 2=2.379 \AA$ and $\mathrm{H} 16 \mathrm{~b} \cdots \mathrm{O} 1=2.430 \AA$ ) .

Three new complexes showed simple $\mathrm{D}_{4 \mathrm{~h}}$ monomer structures. In contrast to the polymers and networks which are mostly constructed from para-substituted pyridine ligands, the monomers contained more sterically-encumbered ligands: 3-MePy (3), 2-PhPy (18), and 3-PhPy (19). As shown in Figure 4, compound 19 could reasonably be regarded as a chain, having Cu'.'S connections of 3.2499(5) that are only slightly greater than the $3.2 \AA$ van der Waals radius sum. However, compounds $\mathbf{3}$ and $\mathbf{1 8}$ have even longer Cu'S S distances (3.3869(7) $\AA$ and $4.816 \AA$, respectively), making them less chain-like. Compound $\mathbf{3}$ shows a clear $\pi$-stacking arrangement amongst the pyridyl rings with a centroid"'centroid distance of $3.528 \AA$. Although the phenyl rings in 18 are properly oriented for $\pi$-stacking, the 
centroid"'centroid distance of over $4 \AA$ obviates this interaction. Compound 19 shows an edge-to-face $\pi$ stacking interaction, but it is not within the putative chain.

Figure 4. X-ray structures of new $\mathrm{D}_{4 \mathrm{~h}}$ monomer complexes: trans-[Cu(NCS)$\left.)_{2}(3-\mathrm{MePy})_{2}\right] \quad 3$, trans$\left[\mathrm{Cu}(\mathrm{NCS})_{2}(2-\mathrm{PhPy})_{2}\right] 18$, and trans-[Cu(NCS $\left.)_{2}(3-\mathrm{PhPy})_{2}\right]$ 19. See Figure 1 for atom color key.
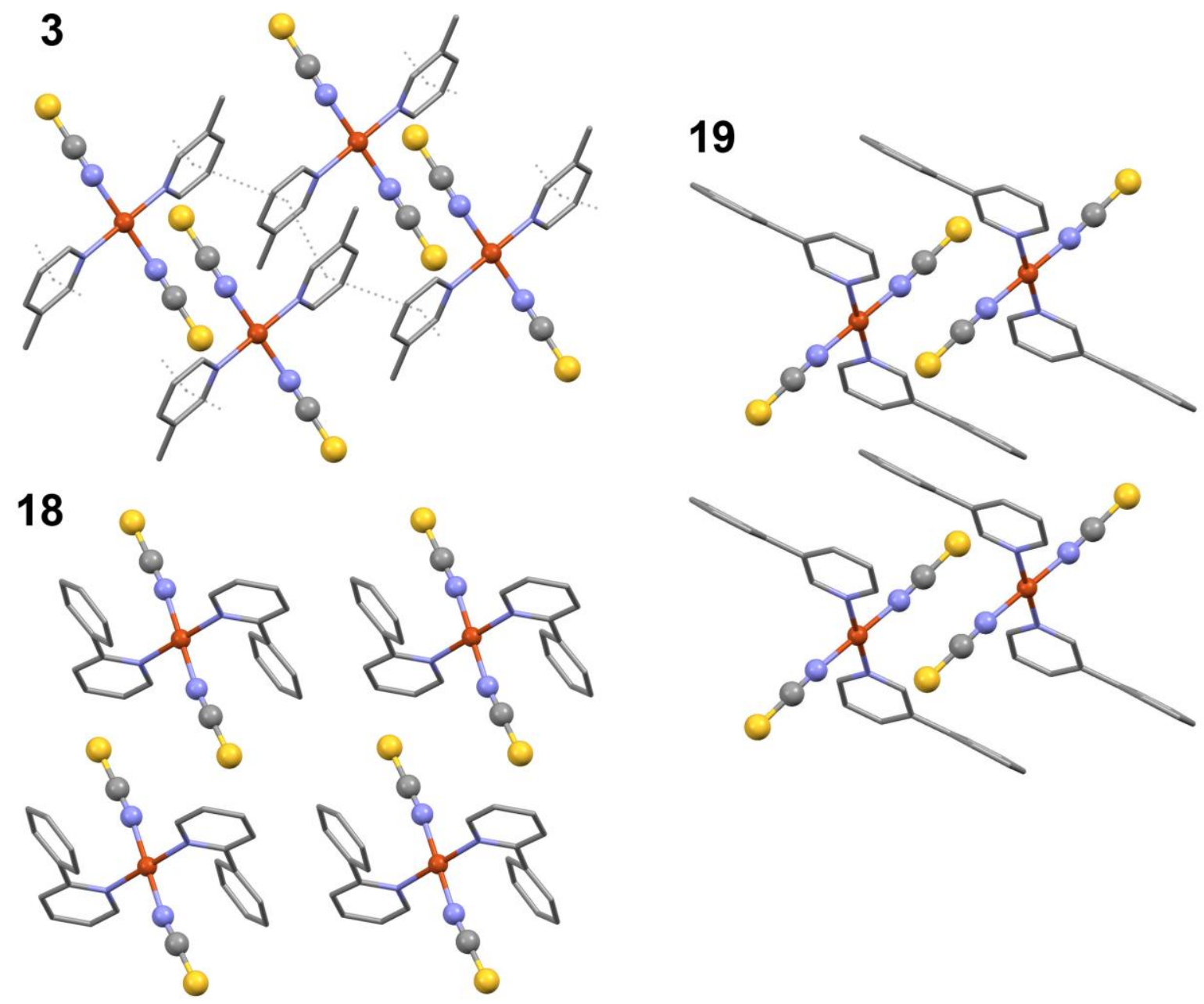

The fourth category of complexes listed in Table 5 is described as $C_{4 v}$ dimers. These species are related to the $\mathrm{D}_{4 h}$ chains, however, while one Cu'S connection is clearly bridging, the other is too long. Pairwise bridging cuts the putative chain into dimer units. Only one such complex had previously been identified. Three new $\mathrm{C}_{4 \mathrm{v}}$ dimer complexes 7, 8, and $\mathbf{1 0}$ are presented in Figure 5. The known complex, 
12b, is shown above in Figure 1 [10]. Complex 8 is the most chain-like of the three; nevertheless, the non-bonded $\mathrm{Cu}$ '. S distance is quite large at $3.4877(8) \AA$. . In two other complexes dimers further interact via face-to-face $\pi$-stacking arrangements: centroid"'centroid distance $=3.697 \AA$ in 10 and $3.782 \AA$ in $12 b$.

Figure 5. X-ray structures of new $\mathrm{C}_{4 v}$ dimer complexes: trans-[Cu(NCS)$\left.)_{2}(2-\mathrm{BrPy})(3-\mathrm{BrPy})\right]$ 7, trans$\left[\mathrm{Cu}(\mathrm{NCS})_{2}(3-\mathrm{BrPy})_{2}\right]$ 8, and trans-[Cu(NCS $\left.)_{2}(3-\mathrm{MeOPy})_{2}\right]$ 10. See Figure 1 for atom color key.
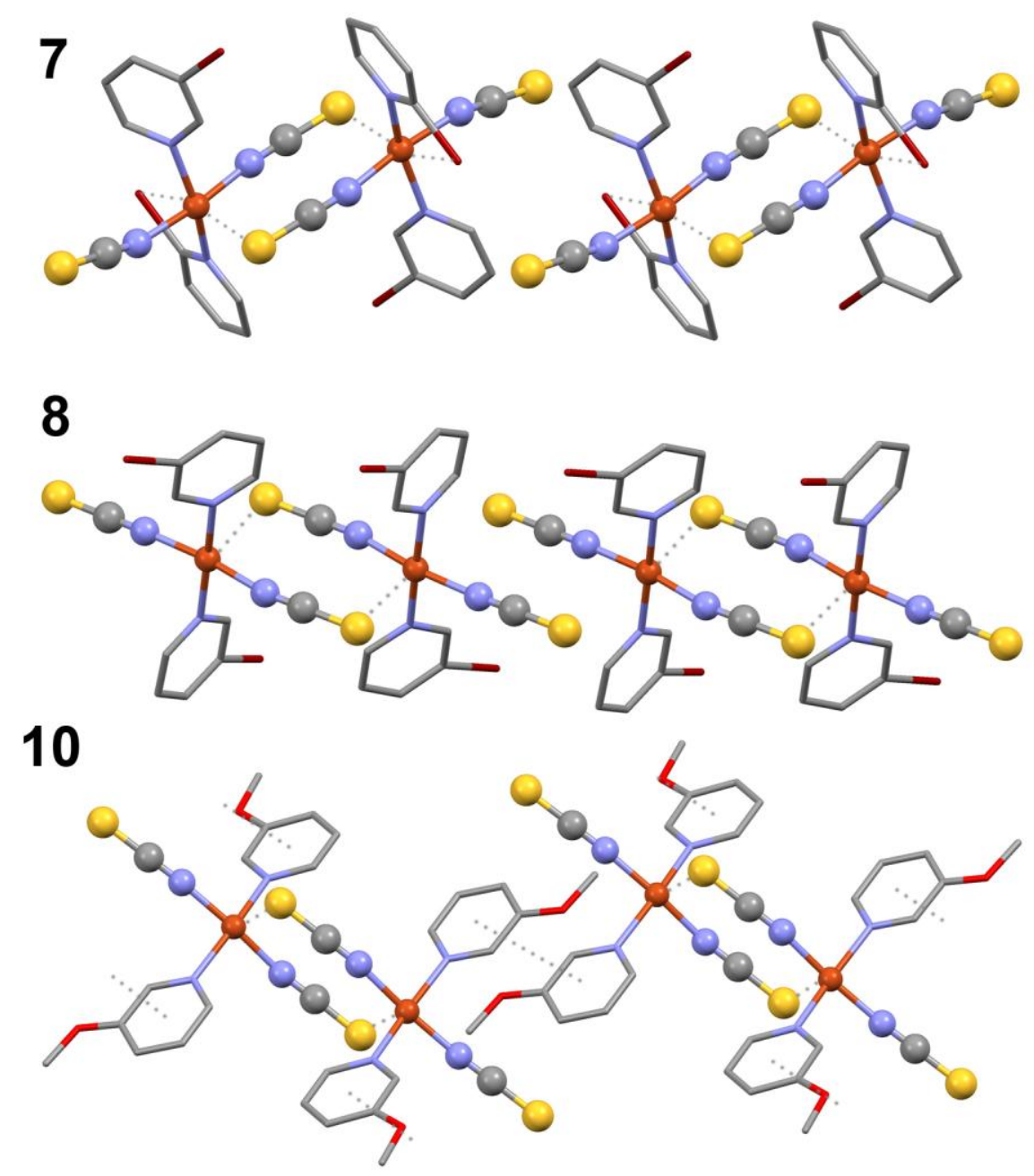

Compound $\mathbf{7}$ deserves particular attention. Crystals of 2 -substituted pyridines proved difficult to produce in the current study. Thus, 2-CIPy and 2-BrPy did not yield crystalline products when reacted with $\mathrm{Cu}(\mathrm{NCS})_{2}$. However, the use of a 9:1 mixture of 2-BrPy:3-BrPy yielded interesting complex 7, which 
contains pairs of both ligands within its $\mathrm{C}_{4 \mathrm{v}}$ dimers. In 7 the interruption of the chain structure appears to be the result of a remarkable interaction between $\mathrm{Cu}$ and the 2 -bromo substituent $(\mathrm{Cu}-\mathrm{Br}=3.1364(5)$ $\AA ̊$ ). This value is within the van der Waals radius sum for $\mathrm{Cu}-\mathrm{Br}$ of $3.25 \AA$ [22]. Further supporting the idea of $\mathrm{Cu}-\mathrm{Br}$ bonding is the highly non-linear $\mathrm{N}_{\mathrm{Py}}-\mathrm{Cu}-\mathrm{N}_{\mathrm{Py}}$ bond angle of $162.79(9)^{\circ}$ arising from the strain of a CuNCBr four-membered ring. Thus, at least in the case of 7, the chelating ability of the 2-BrPy ligand accounts for the lack of chain formation. As with 19, 7 shows an edge-to-face $\pi$-stacking interaction that is not within the putative chain.

As an alternative to the formation of a pairwise $\mathrm{Cu}_{2}(\mathrm{SCN})_{2}$ connection that produces dimers, bridging by a single thiocyanate can also result in chain formation. Complexes having this arrangement may be described as $C_{4 v}$ chains. Only two examples are known, 17 and 23 [12],[13]. Compound $\mathbf{1 7}$ is shown in Figure 1. The resulting square-wave chains in both complexes are fully isolated from one another with no evidence of $\pi$-stacking or other inter-chain interactions.

The few complexes that incorporated $\mathrm{MeOH}$ ligands were all monomeric. The current study added three such species to the known octahedral di-MeOH complex 27 (see Figure 1) [14]. As shown in Figure 6, two new octahedral complexes $12 \mathrm{a}$ and 14 were also di-MeOH-containing octahedra. A similar interaction is seen in the 2-benzoylpyridine complex $\mathbf{2 5}$, wherein the carbonyl oxygen atoms from the ligands chelate so as to occupy the final two octahedral positions [19],[20]. New complex 2a is a unique $\mathrm{C}_{4 \mathrm{v}}$ mono-solvate. In the case of both $12 \mathrm{a}$ and $2 \mathrm{a}$, solvent-free analogs exist, and both $12 \mathrm{a}$ and 14 yielded elemental analysis results corresponding to loss of one or both solvent molecules after shipping (Table 3). As noted above, $\mathbf{1 2} \mathbf{b}$ forms $C_{4 v}$ dimers [10], while $\mathbf{2 b}$ forms $D_{4 h}$ networks [15]. Octahedral species $\mathbf{1 2 a}$ and $\mathbf{1 4}$ are strict monomers having no inter-molecular interactions. However, in $\mathbf{2 a} \pi$ stacking produces parallel chain arrangements (centroid“'centroid = $3.820 \AA$ ). In each of these species, the $\mathrm{Cu}-\mathrm{O}$ bond is longer than the average $\mathrm{Cu}-\mathrm{O}$ bond length of $2.29(3) \AA$ [23]: 2.363(3) $\AA$ for $2 \mathrm{a}$, 
2.4225(12) $\AA$ for $12 a, 2.4222(16) \AA$ for $14,2.4346(19) \AA$ for $\mathbf{2 6}$, and $2.430 \AA$ for $\mathbf{2 7}$. This is the result of J-T distortion.

Figure 6. X-ray structures of new methanol-containing complexes: trans-[Cu(NCS $\left.)_{2}(3-\mathrm{AcPy})_{2}(\mathrm{MeOH})_{2}\right]$ 12a, trans-[Cu(NCS $\left.)_{2}(3-\mathrm{NCPy})_{2}(\mathrm{MeOH})_{2}\right]$ 14, and trans-[Cu(NCS $\left.)_{2}(2-\mathrm{MePy})_{2}(\mathrm{MeOH})\right]$ 2a. See Figure 1 for atom color key.
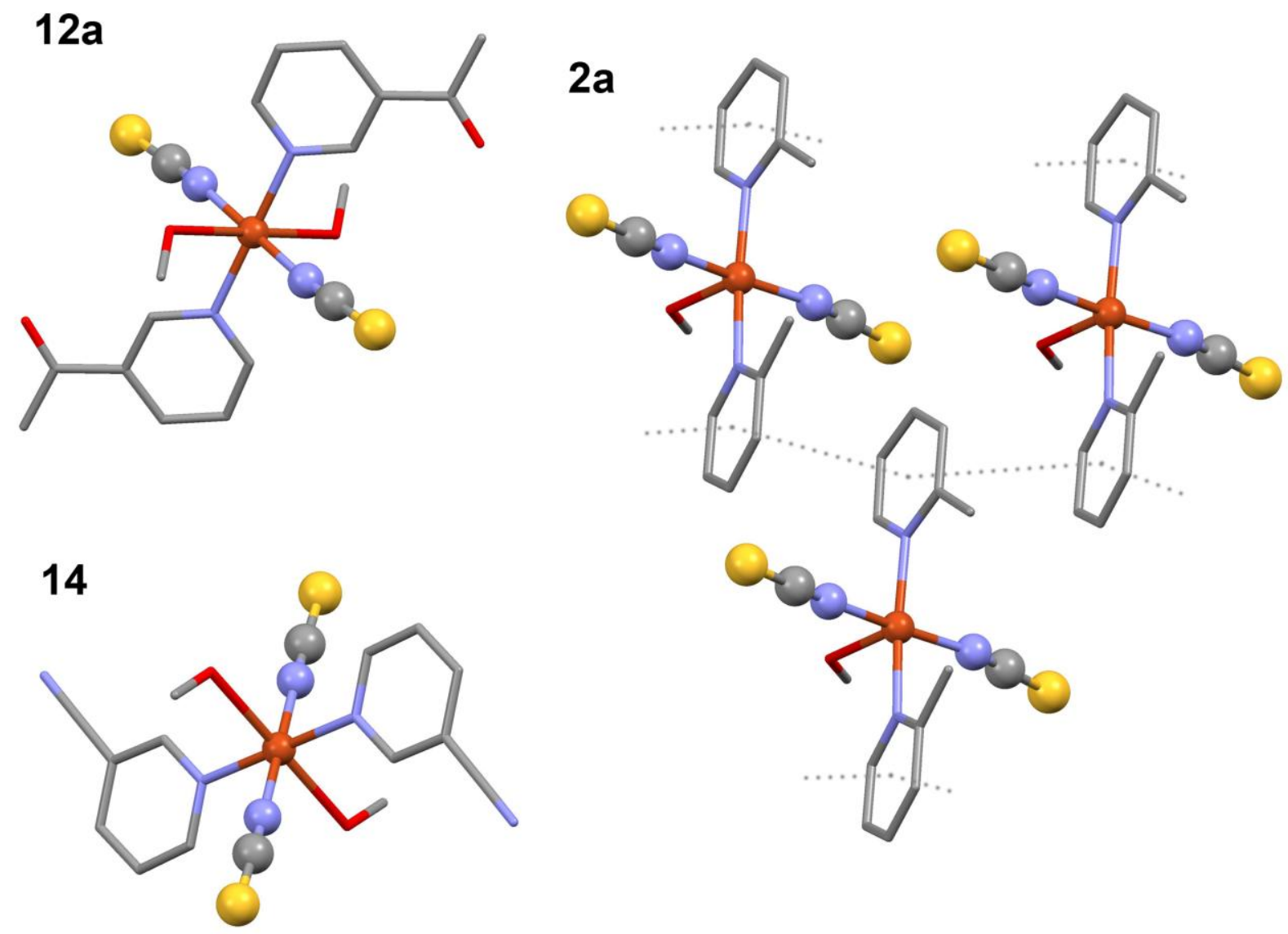

An unexpected result was encountered in the reaction of $\mathrm{Cu}(\mathrm{NCS})_{2}$ with $2-\mathrm{NH}_{2} \mathrm{Py}$ in $\mathrm{MeOH}$. The methanol ligand was deprotonated to form a methoxy-bridged dimer, $\left[\mathrm{Cu}_{2}(\mathrm{NCS})_{2}(\mu-\mathrm{OMe})_{2}\left(2-\mathrm{NH}_{2} \mathrm{Py}\right)_{2}\right]$, 16. A likely explanation for this ligand deprotonation is associated with the enhanced basicity of 2$\mathrm{NH}_{2} \mathrm{Py}$. As with the other $\mathrm{Cu}(\mathrm{II})$ complexes in the study, the thiocyanate ligands in $\mathbf{1 6}$ attach primarily through $\mathrm{N}$-bonding. In addition, a relatively long $\mathrm{Cu}-\mathrm{S}$ bond of $2.8484(10)$ links the dimers into a sheet 
structure. The $\mathrm{Cu}-\mathrm{O}$ bond is undistorted and lies well within the standard range at $1.922(2) \AA$. The methoxy group interacts with a face of the pyridine ring $\left(\mathrm{C}_{\text {Me }} \cdots\right.$ centroid $\left.=3.561 \AA\right)$.

Figure 7. X-ray structure of $\left[\mathrm{Cu}_{2}(\mathrm{NCS})_{2}(\mu-\mathrm{OMe})_{2}\left(2-\mathrm{NH}_{2} \mathrm{Py}\right)_{2}\right]$, 16. See Figure 1 for atom color key.

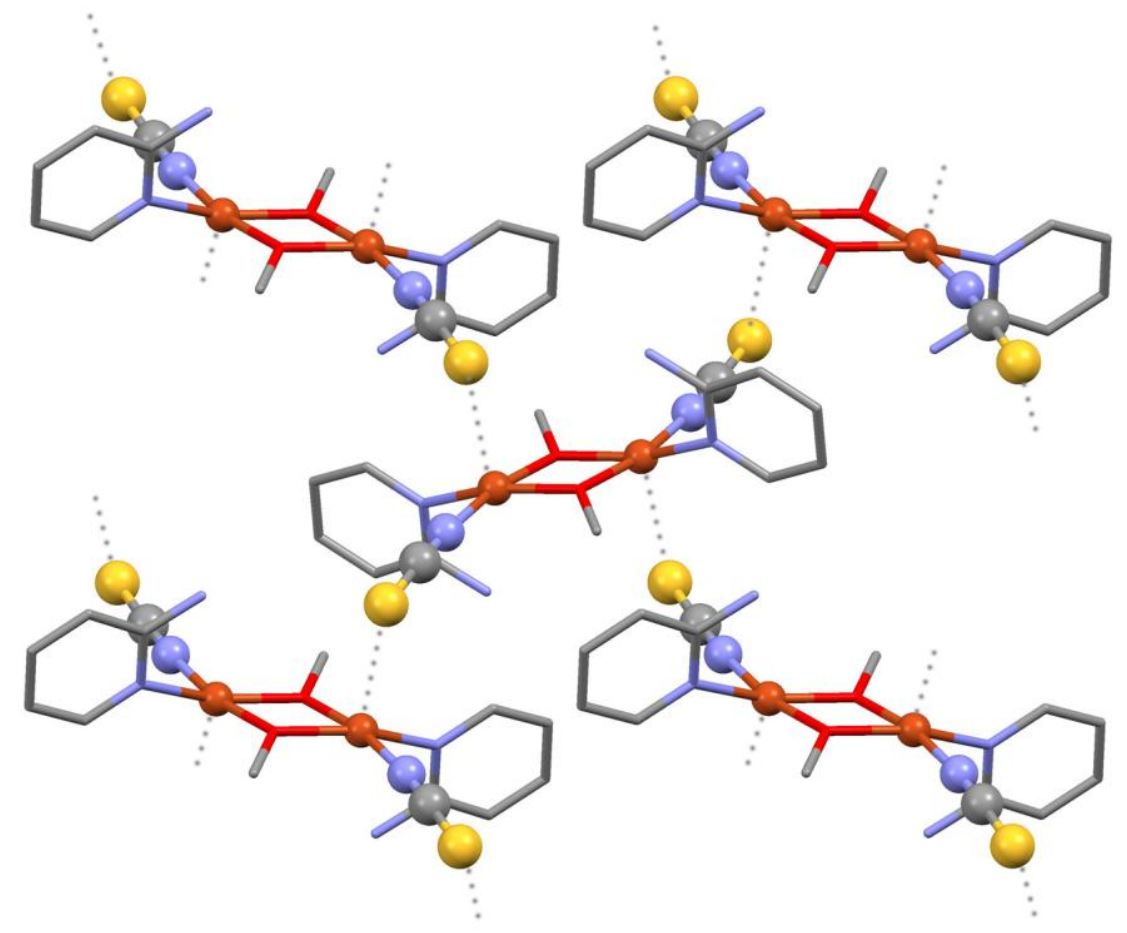

The use of the compact bridging pyridine-type ligands, $L L=4,4^{\prime}$-dipyridyl (Bpy) and pyrazine (Pyz), resulted in trans-[Cu(NCS) $\left.)_{2}(\mathrm{LL})\right]$ complexes. In order to obtain crystals of these insoluble compounds, a methanolic solution of $\mathrm{Cu}(\mathrm{NCS})_{2}$ was layered with a methanolic solution of the ligand. Slow diffusion produced crystals of 21 ( $L L=$ Bpy) and $22(L L=$ Pyz), see Figure 8 . These are the first reported examples of $\mathrm{Cu}(\mathrm{NCS})_{2}$ units linked by bridging diamine ligands. In these species $\cdots(\mathrm{LL})-\mathrm{Cu}(\mathrm{NCS})_{2}-$ $(\mathrm{LL})-\mathrm{Cu}(\mathrm{NCS})_{2}{ }_{2} \cdots$ chains are cross-linked by long $\mathrm{Cu}-\mathrm{S}$ bonds that nonetheless lie within bonding range:

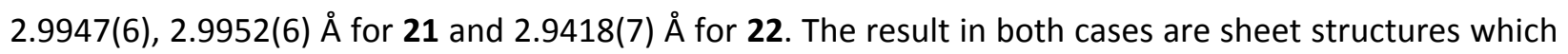
have no further interaction between layers. In the case of $\mathbf{2 1}$ the infinite chains of $\mathrm{Cu}(\mathrm{NCS})_{2}$ propagate in two orthogonal directions, and a weak edge-to-face $\pi$-stacking is present within the sheet. By contrast, 
in 22 the crystallographically independent unit consists of $\mathrm{Cu}_{\frac{1}{2}}(\mathrm{NCS})(\mathrm{Pyz})_{\frac{1}{2}}$, causing all $\mathrm{Cu}(\mathrm{NCS})_{2}$ chains to be oriented identically due to symmetry equivalence.

Figure 8. X-ray structures of network complexes: trans-[Cu(NCS)$\left.)_{2}(\mathrm{Bpy})\right] 21$ and trans-[Cu(NCS)$\left.)_{2}(\mathrm{Pyz})\right] 22$. See Figure 1 for atom color key.

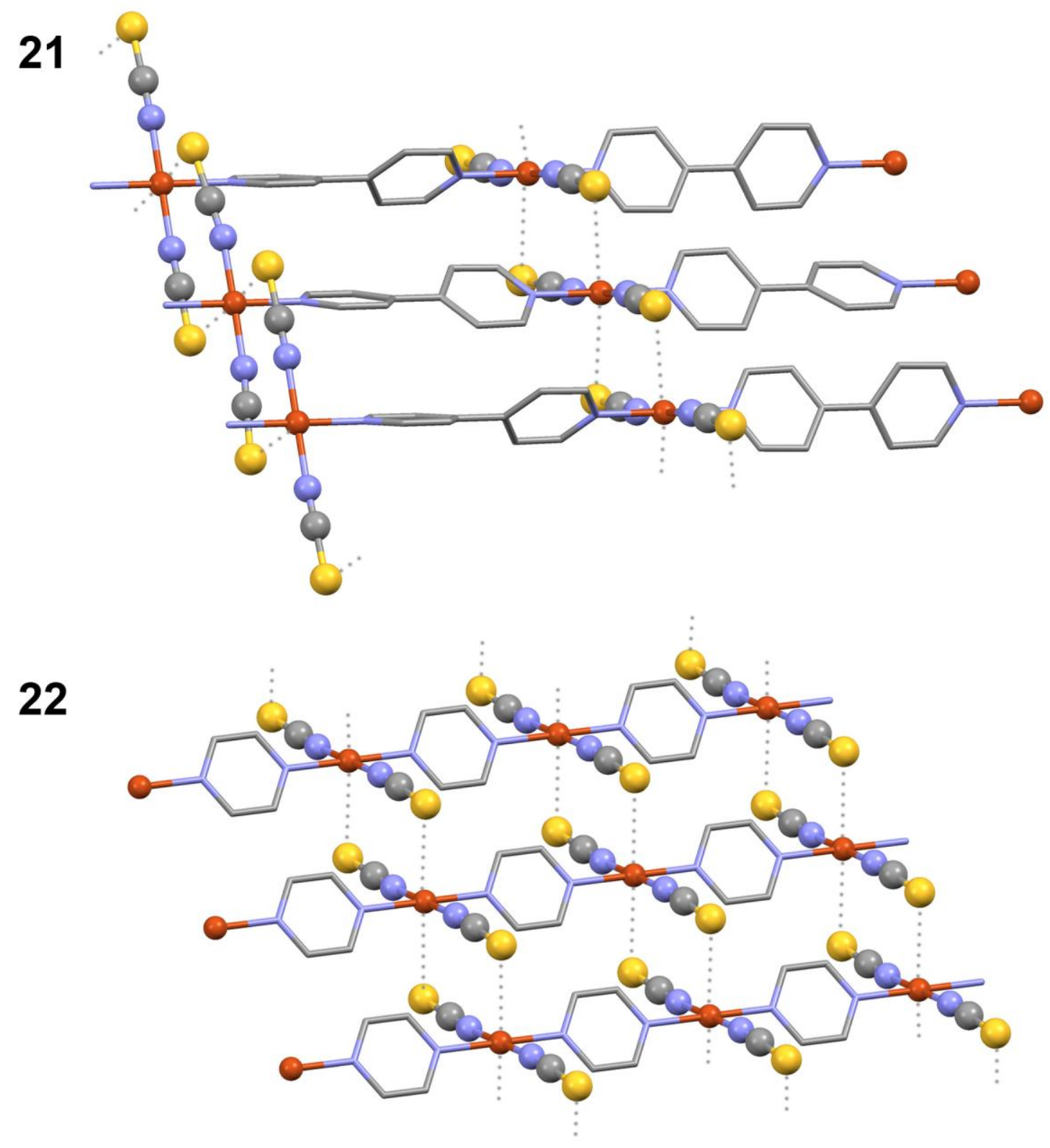

Discussion: 
In examining all of the foregoing structural data, it is apparent that pyridine substituents play a significant role in allowing thiocyanate sulfur to bond to copper in these compounds. In Figure $9 \mathrm{Cu}$ '.' distance is plotted versus substituent position on pyridine. Data are included only for formally square planar complexes, i.e. those without solvent. Methoxy-bridged complex $\mathbf{1 6}$ is also omitted from the data. Bridging Bpy and Pyz ligands are treated as 4-substituted pyridines, while Pdz is treated as having no substituent. A general trend toward shorter $\mathrm{CU}^{\prime \prime} \mathrm{S}$ bonds is apparent as sterically congested 2- and 3substituents are replaced with non-demanding 4- positions (or no substituent). The scatter in the graph is likely due to a number of factors. But one of these is the fact that no distinction was made as to the size of the substituent. The baseline for these $\mathrm{Cu}$ '. $\mathrm{S}$ interactions is a relatively long distance due to the JT effect; nevertheless, it is apparent that 2- or 3- substitution on the pyridine ligands can increase them beyond the point of any relevance to bonding. This leaves an opening for replacement in the potentially (distorted) octahedral $\mathrm{Cu}(\mathrm{II})$ coordination sphere. Based on the foregoing results, the options include: solvent coordination, chelation of an available donor atom, or simply leaving the site vacant.

Figure 9. Correlation of $\mathrm{Cu}$ '.'S bond length with pyridine substituent position. 


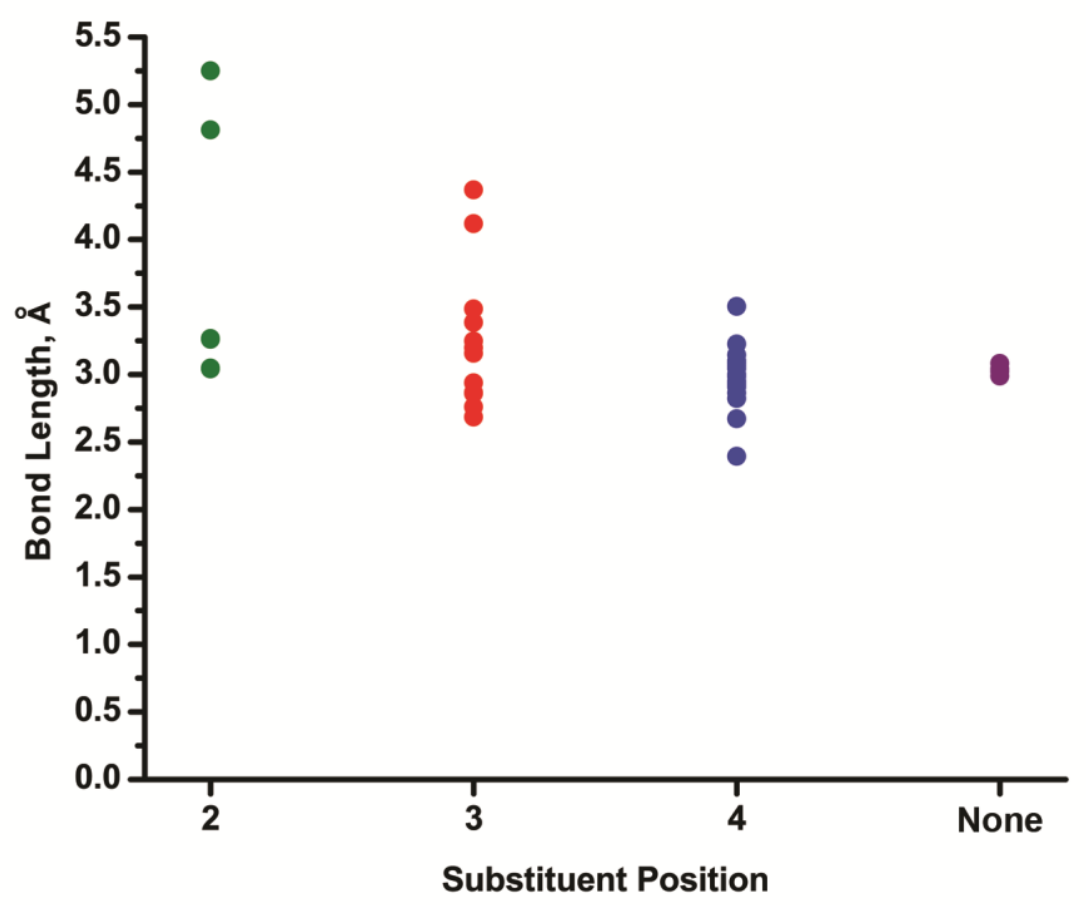

As we complete our discussion, let's return to the questions we initially set out to answer.

1. What would be the favored metal coordination number? It seems that $\mathrm{Cu}$ (II) favors the standard J-T distorted octahedral geometry, so long as there is an available donor. This is typically thiocyanate sulfur. However, sometimes a solvent molecule is utilized. In addition, we have uncovered a 5-coordinate $\mathrm{MeOH}$ complex, $2 \mathrm{a}$, and seen isolated $\mathrm{D}_{4 \mathrm{~h}}$ units.

2. Would the coordination geometry be cis or trans? Trans geometry appears to be the rule for all of these complexes. The lack of a trans effect, wherein donor ligands tend to be oriented trans to acceptor ligands, is perhaps surprising. However, both thiocyanate and pyridine exhibit mild $\pi$-acceptance behavior.

3. Would monodentate $S$ or $N$ thiocyanate-metal linkage, or bridging linkage be favored? Although most of the complexes characterized herein are formally thiocyanate-bridged, it is apparent that $\mathrm{Cu}-\mathrm{N}$ is the primary linkage. The $\mathrm{Cu}-\mathrm{NCS}$ bond lengths are all nearly $2.0 \AA$, while the $\mathrm{Cu}-\mathrm{SCN}$ bonds are mostly $>2.8 \AA$, placing them well above the norm of $2.3 \AA$. Furthermore, the few 
monodentate NCS ligands are bonded to Cu through N. Copper(II) is of intermediate hardness, making $\mathrm{N}$-bonding reasonable. Nevertheless, it is noteworthy that the use of non-aromatic amines as ancillary ligands can result in either $\mathrm{N}$ - or S-bound $\mathrm{Cu}(\mathrm{II})$ thiocyanate [6]. In contrast, the soft $\mathrm{Cu}(\mathrm{l})$ almost always bridges. Amongst a series of $20 \mathrm{CuSCN}$ complexes of pyridine, amine, and sulfide ligands that we recently reported, 19 were bridged, with the average $\mathrm{Cu}-\mathrm{S}=$ 2.37(8) $\AA[31]-[33]$. Clearly, in these $\mathrm{Cu}(\mathrm{I})$ complexes the $\mathrm{Cu}-\mathrm{S}$ is stronger than in the $\mathrm{Cu}(\mathrm{II})$ species studied here. Interestingly, the remaining $\mathrm{Cu}(\mathrm{I})$ species in the previous studies, monomeric $\left[(\mathrm{CuNCS})(3-\mathrm{EtPy})_{3}\right]$, proved to have N-bound thiocyanate.

4. Would a consistent Jahn-Teller (J-T) distortion be evident? J-T distortion is consistently seen for octahedral $\mathrm{Cu}(\mathrm{II})$ complexes. The thiocyanate series discussed herein is no exception. The distortions seen are always tetragonal "z-out" type in which a $\mathrm{Cu}-\mathrm{S}$ or $\mathrm{Cu}-\mathrm{O}$ bond is elongated.

5. Would the tendency of thiocyanate to bridge metal centers consistently result in network formation? Chain structures consisting of $\mathrm{Cu}_{2}(\mathrm{NCS})_{2}$ rings are the norm for the $\mathrm{Cu}(\mathrm{II})$ thiocyanate pyridine system. Nevertheless, there are other options. In some cases the rings are opened, producing 2-D sheet structures or in one case a helix. In some cases only one of the thiocyanate ligands formally bridges metal centers. The result is cleavage of the chains into dimeric units or, when $\mathrm{Cu}_{2}(\mathrm{NCS})_{2}$ rings are absent, cleavage of the sheets into square wave chains.

6. Would $\mathrm{MeOH}$ coordination be observed? Methanol coordination has been found in only a few cases and is apparently disfavored over thiocyanate bridging in general. All of the $\mathrm{MeOH}$ complexes seen involve sterically demanding 2- or 3-substituted pyridines.

7. Could the relative stability of $\mathrm{CU}(\mathrm{II})$ vs. $\mathrm{Cu}(\mathrm{I})$ thiocyanate be assessed in $\mathrm{MeOH}$ ? It was noted that $\mathrm{Cu}(\mathrm{II})$ solutions in $\mathrm{MeOH}$ containing thiocyanate were thermally unstable. These solutions formed insoluble tan CuSCN over the course of minutes at ambient temperature and over the course of days at $-5^{\circ} \mathrm{C}$. 


\section{Conclusions:}

We have prepared a series of trans-[Cu(NCS $\left.)_{2}(\mathrm{XPy})_{2}\right]$ complexes by reacting copper(II) nitrate, ammonium thiocyanate and substituted pyridines $(\mathrm{XPy})$ in methanol. Unlike the parent $\mathrm{Cu}(\mathrm{NCS})_{2}$, the dark green or blue pyridine complexes appear to be thermally stable, with the exception of solvent loss when $\mathrm{MeOH}$ ligands are present. Infrared analysis of the complexes revealed relatively high frequency $\mathrm{C} \equiv \mathrm{N}$ bands suggestive of bridging thiocyanate. Relatively high frequency $\mathrm{S}-\mathrm{C}$ bands were consistent with primary N-bonding.

Comparison of 20 new and 12 known trans-[Cu(NCS $\left.)_{2}(\mathrm{XPy})_{2}\right]$ structures led to the following general conclusions. Thiocyanate ligands bind to copper primarily through nitrogen, but usually also exhibit long $\mathrm{Cu}-\mathrm{S}$ interactions. These long interactions are also associated with Jahn-Teller distortion of the $\mathrm{Cu}(\mathrm{II})$ octahedral coordination sphere. Most commonly, $\mathrm{Cu}_{2}(\mathrm{NCS})_{2}$ dimers are formed, resulting in edge-sharing of the octahedra within chains. In some cases the cyclic dimers are lacking, resulting in 2-D sheets of CuSCN chains cross-linked at $\mathrm{Cu}$. Chain and sheet formation is truncated in some cases to produce dimers or monomers, usually when 2- or 3-position substituents are present on the pyridine ligands. Incorporation of methanol ligand in a few complexes produces isolated distorted octahedra, trans-[Cu(NCS $\left.)_{2}(\mathrm{XPy})_{2}(\mathrm{MeOH})_{2}\right]$, having long $\mathrm{Cu}-\mathrm{O}$ bonds. $\mathrm{A}$ unique square pyramid monomer trans$\left[\mathrm{Cu}(\mathrm{NCS})_{2}(2-\mathrm{MePy})_{2}(\mathrm{MeOH})\right]$ was identified, as was a methoxy-bridged dimer, $\left[\mathrm{Cu}_{2}(\mathrm{NCS})_{2}(\mu-\mathrm{OMe})_{2}(2-\right.$ $\left.\mathrm{NH}_{2} \mathrm{Py}\right)_{2}$ ] that forms 2-D sheets through long $\mathrm{Cu}-\mathrm{S}$ bridging, and a chelating 2-BrPy ligand with a long $\mathrm{Cu}-$ $\mathrm{Br}$ bond in trans-[Cu(NCS)$\left.)_{2}(2-\mathrm{BrPy})(3-\mathrm{BrPy})\right]$. Finally, replacement of two pyridine ligands with $4,4^{\prime}-$ dipyridyl (Bpy) or pyrazine (Pyz) results in cross-linking of the $\left[\mathrm{Cu}_{2}(\mathrm{NCS})_{2}\right]_{\infty}$ chains to form sheets.

Given the ease of preparation, diversity of crystal structures, and the chance to examine the various bonding questions addressed herein, the trans-[Cu(NCS $\left.)_{2}(\mathrm{XPy})_{2}\right]$ represents an excellent system 
for laboratory instruction in coordination chemistry at university chemistry departments with access to X-ray crystallography.

Acknowledgements. X-ray equipment was obtained with support from the NSF (CHE-0443345) and the College of William and Mary.

Appendix A. Supplementary data. Crystallographic data for the structures reported in this paper have been deposited with the Cambridge Crystallographic Data Centre as supplementary publication with. CCDC 1500158-1500177 contain the supplementary crystallographic data for the compounds reported herein. These data can be obtained free of charge via http://www.ccdc.cam.ac.uk/conts/retrieving.html, or from the Cambridge Crystallographic Data Centre, 12 Union Road, Cambridge CB2 1EZ, UK; fax: (+44) 1223-336-033; or e-mail: deposit@ccdc.cam.ac.uk. Supplementary data associated with this article, consisting of IR spectra and further crystal structure views, can be found, in the online version, at ...

\section{References:}

(1) S. Qiu, M. Xue, G. Zhu, Chem. Soc. Rev. 43 (2014) 6116-6140.

(2) L.E. Kreno, K. Leong, O.K. Farha, M. Allendorf, R.P. Van Duyne, J.T. Kupp, Chem. Rev. 112 (2012) 1105-1125.

(3) J. Rocha, L.D. Carlos, F.A. Almeida Paz, D. Ananias, Chem. Soc. Rev. 40 (2011) 926-940.

(4) J.-R. Li, R.J. Kuppler, H.-C. Zhou, Chem. Soc. Rev. 38 (2009) 1477-1504.

(5) A.H. Norbury, Adv. Inorg. Radiochem. 17 (1975) 231-386.

(6) M. Kabesova, J. Gazo, Chem. Zvesti 34 (1980) 800-841.

(7) D. Tudela, J. Chem. Educ. 70 (1993) 174.

(8) J. Soldanova, M. Kabesova, J. Gazo, Inorg. Chim. Acta 76 (1983) L203-L204.

(9) G. Chen, Z.-P. Bai, S.-J. Qu, Acta Crystallogr., Sect. E 61 (2005) m2718-m2719.

(10)B. Cobeljic, A. Pevec, I. Turel, V. Spasojevic, M. Milcic, D. Mitic, D. Sladic, K. Andelkovic, Polyhedron 69 (2014) 77-83.

(11)M. Dakovic, Z. Jaglicic, B. Kozlevcar, Z. Popovic, Polyhedron 29 (2010) 1910-1917. 
(12)B. Machura, A. Switlicka, J. Mrozinski, B. Kalinska, R. Kruszynski, Polyhedron 52 (2013) 12761286.

(13)B.-Y. Wang, W.-J. Xu, W. Xue, R.-B. Lin, Z.-Y. Du, D.-D. Zhou, W.-X. Zhang, X.-M. Chen, Dalton Trans. 43 (2014) 9008-9011.

(14)F. Robert, A.D. Naik, B. Tinant, R. Robiette, Y. Garcia, Chem.-Eur. J. 15 (2009) 4327-4342.

(15)A.S. Antsyshkina, M.A. Porai-Koshits, G.G. Sadikov, M. Kabesova, J. Gazo, Soviet J. Coord. Chem. 7 (1981) 497-506.

(16)M. Kabesova, M. Dunaj-Jurco, J. Soldanova, Inorg. Chim. Acta 130 (1987) 105-111.

(17)R.E. Marsh, Acta Crystallogr., Sect. B 55 (1999) 931-936.

(18)Z. Koziskova, J. Kozisek, M. Kabesova, Polyhedron 9 (1990) 1029-1034.

(19)J.G. Malecki, B. Machura, A. Switlicka, J. Kusz, Polyhedron 30 (2011) 410-418.

(20)T. Ghosh, T. Chattopadhyay, S. Das, S. Mondal, E. Suresh, E. Zangrando, D. Das, Cryst. Growth Des. 11 (2011) 3198-3205.

(21)Y. Bai, G.-S. Zheng, D.-B. Dang, Y.-N. Zheng, P.-T. Ma, Spectrochim. Acta A 79 (2011) 1338-1344.

(22)A. Bondi, J. Phys. Chem. 68 (1964) 441-451.

(23)C.R. Groom, I.J. Bruno, M.P. Lightfoot, S.C. Ward, Acta Crystallogr., Sect B. 72 (2016). 171-179. CCDC accessed, October 26, 2016.

(24)P.M. Graham, R.D. Pike, M. Sabat, R.D. Baily, W.T. Pennington, Inorg. Chem. 39 (2000) 51215132.

(25)SAINT PLUS: Bruker Analytical X-ray Systems: Madison, WI, 2001.

(26)SADABS: Bruker Analytical X-ray Systems: Madison, WI, 2001.

(27)G.M. Sheldrick, Acta Crystallogr., Sect. A 64 (2008) 112-122.

(28)C.B. Hubschle, G.M. Sheldrick, B. Dittick, J. Appl. Cryst. 44 (2011) 1281-1284.

(29)K. Nakamoto (1997) Infrared and Raman Spectra of Inorganic and Coordination Compounds, Part B: Applications in Coordination, Organometallic, and Bioinorganic Chemistry, $5^{\text {th }}$ ed. New York: Wiley Interscience, pp. 116-121.

(30)C. Janiak, Dalton Trans. (2000) 3885-3896.

(31)K.M. Miller, S.M. McCullough, E.A. Lepekhina, I.J. Thibau, R.D. Pike, X. Li, J.P. Killarney, H.H. Patterson, Inorg. Chem. 50 (2011) 7239-7249.

(32)G. Ayala, R.D. Pike, Polyhedron 115 (2016) 242-246.

(33)G. Ayala, T.A. Tronic, R.D. Pike, Polyhedron 115 (2016) 257-263. 
Table 1. Synthesis Results.

\begin{tabular}{|c|c|c|c|c|c|c|c|}
\hline & Complex & $\begin{array}{c}\% \\
\text { Yield }\end{array}$ & $\mathrm{Cu}$ analysis ${ }^{\mathrm{a}}$ & C analysis ${ }^{a}$ & $\mathrm{H}$ analysis ${ }^{\mathrm{a}}$ & $\mathrm{N}$ analysis ${ }^{\mathrm{a}}$ & Ref. \\
\hline $1 \mathrm{a}$ & trans- $\left[\mathrm{Cu}(\mathrm{NCS})_{2}(\mathrm{Py})_{2}\right]^{\mathrm{b}}$ & 74.8 & $18.7(18.8)$ & $42.4(42.7)$ & $3.45(3.55)$ & $14.0(14.1)$ & 9 \\
\hline 1b & trans- $\left[\mathrm{Cu}(\mathrm{NCS})_{2}(\mathrm{Py})_{2}\right]^{\mathrm{c}}$ & - & - & - & - & - & 8 \\
\hline $2 a$ & trans-[Cu(NCS $\left.)_{2}(2-\mathrm{MePy})_{2}(\mathrm{MeOH})\right]^{\mathrm{d}}$ & 66.8 & $15.5(16.0)$ & $44.4(45.3)$ & $4.39(4.55)$ & $14.1(14.1)$ & this work \\
\hline $2 b$ & trans- $\left[\mathrm{Cu}(\mathrm{NCS})_{2}(2-\mathrm{MePy})_{2}\right]^{\mathrm{b}}$ & - & - & - & - & - & 15 \\
\hline 3 & trans- $\left[\mathrm{Cu}(\mathrm{NCS})_{2}(3-\mathrm{MePy})_{2}\right]$ & 85.8 & $17.9(17.4)$ & $46.1(46.0)$ & $3.93(3.86)$ & $15.3(15.3)$ & this work \\
\hline 4 & trans- $\left[\mathrm{Cu}(\mathrm{NCS})_{2}(4-\mathrm{MePy})_{2}\right]$ & 62.3 & $17.2(17.4)$ & $45.7(46.0)$ & $3.78(3.86)$ & $15.5(15.3)$ & this work \\
\hline 5 & trans- $\left[\mathrm{Cu}(\mathrm{NCS})_{2}(3-\mathrm{FPy})_{2}\right]$ & 70.9 & $17.0(17.0)$ & $38.6(38.6)$ & $2.25(2.16)$ & $15.1(15.0)$ & this work \\
\hline 6 & trans $-\left[\mathrm{Cu}(\mathrm{NCS})_{2}(3-\mathrm{ClPy})_{2}\right]$ & 74.3 & $15.2(15.6)$ & $35.2(35.4)$ & $1.97(1.98)$ & $14.0(13.8)$ & this work \\
\hline 7 & trans-[Cu(NCS)$\left.)_{2}(2-\mathrm{BrPy})(3-\mathrm{BrPy})\right]$ & 42.7 & - & - & - & - & this work \\
\hline 8 & trans $-\left[\mathrm{Cu}(\mathrm{NCS})_{2}(3-\mathrm{BrPy})_{2}\right]$ & 53.4 & $12.9(12.8)$ & $29.3(29.1)$ & $1.64(1.63)$ & $11.3(11.3)$ & this work \\
\hline 9 & trans- $\left[\mathrm{Cu}(\mathrm{NCS})_{2}(4-\mathrm{BrPy})_{2}\right]^{\mathrm{c}}$ & - & - & - & - & - & 16,17 \\
\hline 10 & trans- $\left[\mathrm{Cu}(\mathrm{NCS})_{2}(3-\mathrm{MeOPy})_{2}\right]$ & 96.2 & $15.7(16.0)$ & $42.3(42.3)$ & $3.58(3.55)$ & $14.2(14.1)$ & this work \\
\hline 11 & trans- $\left[\mathrm{Cu}(\mathrm{NCS})_{2}(4-\mathrm{MeOPy})_{2}\right]$ & 82.4 & $16.0(16.0)$ & $42.0(42.3)$ & $3.45(3.55)$ & $14.0(14.1)$ & this work \\
\hline $12 a$ & trans $-\left[\mathrm{Cu}(\mathrm{NCS})_{2}(3-\mathrm{AcPy})_{2}(\mathrm{MeOH})_{2}\right]^{\mathrm{d}, \mathrm{e}}$ & 94.7 & $14.7(15.1)$ & $45.0(44.5)$ & $4.31(4.56)$ & $11.3(11.5)$ & this work \\
\hline $12 b$ & trans-[Cu(NCS $\left.)_{2}(3-\mathrm{AcPy})_{2}\right]$ & - & - & - & - & - & 10 \\
\hline $13 a / 13 b$ & trans-[Cu(NCS $\left.)_{2}(4-\mathrm{AcPy})_{2}\right]$ & 90.4 & $14.8(15.1)$ & $45.6(45.5)$ & $3.34(3.34)$ & $13.3(13.3)$ & this work \\
\hline 14 & trans- $\left[\mathrm{Cu}(\mathrm{NCS})_{2}(3-\mathrm{NCPy})_{2}(\mathrm{MeOH})_{2}\right]^{\mathrm{f}}$ & 47.3 & $14.3(14.1)$ & $42.3(42.9)$ & $2.69(2.88)$ & $20.2(20.0)$ & this work \\
\hline $15 a$ & trans- $\left[\mathrm{Cu}(\mathrm{NCS})_{2}(4-\mathrm{NCPy})_{2}\right]^{\mathrm{d}}$ & 55.1 & $16.6(16.5)$ & $43.0(43.4)$ & $2.17(2.08)$ & $21.4(21.7)$ & this work \\
\hline $15 b$ & trans $-\left[\mathrm{Cu}(\mathrm{NCS})_{2}(4-\mathrm{NCPy})_{2}\right]^{\mathrm{c}}$ & - & - & - & - & - & 12 \\
\hline 16 & {$\left[\mathrm{Cu}_{2}(\mathrm{NCS})_{2}(\mu-\mathrm{OMe})_{2}\left(2-\mathrm{NH}_{2} \mathrm{Py}\right)_{2}\right]$} & 46.2 & $25.9(25.8)$ & $34.0(34.1)$ & $3.61(3.67)$ & $17.2(17.0)$ & this work \\
\hline 17 & trans- $\left[\mathrm{Cu}(\mathrm{NCS})_{2}\left(4-\mathrm{NH}_{2} \mathrm{Py}\right)_{2}\right]^{\mathrm{b}}$ & 41.1 & $17.6(17.3)$ & $39.3(39.2)$ & $3.50(3.29)$ & $22.8(22.8)$ & 12,13 \\
\hline 18 & trans-[Cu(NCS $\left.)_{2}(2-\mathrm{PhPy})_{2}\right]$ & 65.9 & $13.4(13.0)$ & $57.7(58.8)$ & $3.67(3.70)$ & $11.4(11.4)$ & this work \\
\hline 19 & trans-[Cu(NCS $\left.)_{2}(3-\mathrm{PhPy})_{2}\right]$ & 83.5 & $13.5(13.0)$ & $58.4(58.8)$ & $3.69(3.70)$ & $11.5(11.4)$ & this work \\
\hline 20 & trans- $\left[\mathrm{Cu}(\mathrm{NCS})_{2}(\mathrm{Pdz})_{2}\right]$ & 78.0 & $19.2(18.7)$ & $35.1(35.3)$ & $2.46(2.37)$ & $24.5(24.7)$ & this work \\
\hline 21 & trans-[Cu(NCS)$\left.)_{2}(\mathrm{Bpy})\right]$ & 47.0 & $19.4(18.9)$ & $42.6(42.9)$ & $2.46(2.40)$ & $16.4(16.7)$ & this work \\
\hline 22 & trans- $\left[\mathrm{Cu}(\mathrm{NCS})_{2}(\mathrm{Pyz})\right]$ & 97.3 & $24.4(24.5)$ & $27.2(27.7)$ & $1.77(1.55)$ & $21.5(21.6)$ & this work \\
\hline 23 & trans- $\left[\mathrm{Cu}(\mathrm{NCS})_{2}(4-\mathrm{MeNHPy})_{2}\right]^{\mathrm{c}}$ & - & - & - & - & - & 13 \\
\hline 24 & trans- $\left[\mathrm{Cu}(\mathrm{NCS})_{2}\left(4-\mathrm{NH}_{2} \mathrm{COPy}\right)_{2}\right]^{\mathrm{C}}$ & - & - & - & - & - & 11 \\
\hline 25 & trans- $\left[\mathrm{Cu}(\mathrm{NCS})_{2}(2-\mathrm{PhCOPy})_{2}\right]^{\mathrm{c}}$ & - & - & - & - & - & 19,20 \\
\hline 26 & trans- $\left[\mathrm{Cu}(\mathrm{NCS})_{2}(4-\mathrm{PhCOPy})_{2}\right]^{\mathrm{c}}$ & - & - & - & - & - & 21 \\
\hline 27 & $\begin{array}{c}\text { trans }-\left[\mathrm{Cu}(\mathrm{NCS})_{2}(3-(2-\right. \\
\left.\mathrm{HOPhCH}=\mathrm{NPy}))_{2}(\mathrm{MeOH})_{2}\right]^{\mathrm{c}}\end{array}$ & - & - & - & - & - & 14 \\
\hline
\end{tabular}

${ }^{a}$ Theoretical value in parenthesis ${ }^{b}$ Confirmed known complex. ${ }^{c}$ Not prepared in this study. ${ }^{d} \mathrm{New}$ polymorph/solvate of known complex. ${ }^{\mathrm{e}} \mathrm{CHN}$ theoretical analysis values for trans-[Cu(NCS)$\left.)_{2}(3-\mathrm{AcPy})_{2}\right]$ ${ }^{\mathrm{f}} \mathrm{CHN}$ theoretical analysis values for trans-[Cu(NCS)$\left.)_{2}(3-\mathrm{NCPy})_{2}(\mathrm{MeOH})\right]$ 
Table 2. Crystal and Structure Refinement Data.

\begin{tabular}{|c|c|c|c|c|}
\hline & $2 a$ & 3 & 4 & 5 \\
\hline CCDC deposit no. & 1500159 & 1500165 & 1500161 & 1500158 \\
\hline color and habit & green block & green block & green plate & green prism \\
\hline size, $\mathrm{mm}$ & $0.27 \times 0.24 \times 0.16$ & $0.42 \times 0.35 \times 0.13$ & $0.27 \times 0.22 \times 0.06$ & $0.46 \times 0.19 \times 0.09$ \\
\hline Formula & $\mathrm{C}_{15} \mathrm{H}_{18} \mathrm{CuN}_{4} \mathrm{OS}_{2}$ & $\mathrm{C}_{14} \mathrm{H}_{14} \mathrm{CuN}_{4} \mathrm{~S}_{2}$ & $\mathrm{C}_{14} \mathrm{H}_{14} \mathrm{CuN}_{4} \mathrm{~S}_{2}$ & $\mathrm{C}_{12} \mathrm{H}_{8} \mathrm{CuF}_{2} \mathrm{~N}_{4} \mathrm{~S}_{2}$ \\
\hline formula weight & 397.99 & 365.95 & 365.95 & 373.88 \\
\hline space group & $P-1$ & $P-1$ & $P 2_{1}{ }^{\mathrm{b}}$ & $P 2_{1} / n$ \\
\hline$a, \AA$ & $7.81280(10)$ & $6.4580(2)$ & $9.5933(2)$ & $8.30210(10)$ \\
\hline$b, \AA$ & $8.3771(2)$ & $8.5419(3)$ & $26.4724(5)$ & $5.91340(10)$ \\
\hline$c, \AA$ & $15.2538(3)$ & $8.6899(3)$ & $9.8066(2)$ & $14.4740(3)$ \\
\hline$\alpha, \operatorname{deg}$ & $82.2620(10)$ & $105.063(2)$ & 90 & 90 \\
\hline$\beta$, deg & $80.7670(10)$ & $110.4590(10)$ & $106.0490(10)$ & $103.3430(10)$ \\
\hline$\gamma, \operatorname{deg}$ & $62.9840(10)$ & $108.4560(10)$ & 90 & 90 \\
\hline volume, $\AA^{3}$ & $875.71(3)$ & $387.23(2)$ & $2393.40(8)$ & $691.40(2)$ \\
\hline Z & 2 & 1 & 6 & 2 \\
\hline$\rho_{\text {calc }}, \mathrm{g} \mathrm{cm}^{-3}$ & 1.509 & 1.569 & 1.523 & 1.796 \\
\hline $\mathrm{F}_{000}$ & 410 & 187 & 1122 & 374 \\
\hline$\mu(\mathrm{Cu} \mathrm{K} \alpha), \mathrm{mm}^{-1}$ & 4.058 & 4.486 & 4.354 & 5.259 \\
\hline Temp., K & 100 & 295 & 100 & 100 \\
\hline residuals: ${ }^{a} \mathrm{R} ; \mathrm{R}_{\mathrm{w}}$ & $0.0452,0.1135$ & $0.0329,0.0918$ & $0.0254,0.0620$ & $0.0242,0.0659$ \\
\hline goodness of fit & 1.180 & 1.081 & 0.994 & 1.077 \\
\hline peak and hole, $\mathrm{e}^{-3}$ & $0.997,-0.598$ & $0.429,-0.224$ & $0.343,-0.257$ & $0.370,-0.522$ \\
\hline
\end{tabular}

${ }^{\mathrm{a}} \mathrm{R}=R_{1}=\Sigma|| F_{o}|-| F_{c}|| / \Sigma\left|F_{o}\right|$ for observed data only. $\mathrm{R}_{\mathrm{w}}=w R_{2}=\left\{\Sigma\left[w\left(F_{o}^{2}-F_{c}^{2}\right)^{2}\right] / \Sigma\left[w\left(F_{o}^{2}\right)^{2}\right]\right\}^{1 / 2}$ for all data. ${ }^{b}$ Flack parameter $=0.466(15)$. 
Table 2. contd.

\begin{tabular}{|c|c|c|c|c|}
\hline & 6 & 7 & 8 & 10 \\
\hline CCDC deposit no. & 1500163 & 1500160 & 1500162 & 1500164 \\
\hline color and habit & green block & green prism & green blade & green prism \\
\hline size, $\mathrm{mm}$ & $0.49 \times 0.25 \times 0.13$ & $0.36 \times 0.11 \times 0.10$ & $0.31 \times 0.08 \times 0.03$ & $0.21 \times 0.13 \times 0.07$ \\
\hline Formula & $\mathrm{C}_{12} \mathrm{H}_{8} \mathrm{Cl}_{2} \mathrm{CuN}_{4} \mathrm{~S}_{2}$ & $\mathrm{C}_{24} \mathrm{H}_{16} \mathrm{Br}_{4} \mathrm{Cu}_{2} \mathrm{~N}_{8} \mathrm{~S}_{4}$ & $\mathrm{C}_{24} \mathrm{H}_{16} \mathrm{Br}_{4} \mathrm{Cu}_{2} \mathrm{~N}_{8} \mathrm{~S}_{4}$ & $\mathrm{C}_{14} \mathrm{H}_{14} \mathrm{CuN}_{4} \mathrm{O}_{2} \mathrm{~S}_{2}$ \\
\hline formula weight & 406.78 & 991.41 & 991.41 & 397.95 \\
\hline space group & $P-1$ & $P-1$ & $P-1$ & $\mathrm{C} 2 / \mathrm{m}$ \\
\hline$a, \AA$ & $6.30120(10)$ & $7.69850(10)$ & $8.0571(2)$ & $14.4710(2)$ \\
\hline$b, \AA$ & $8.1096(2)$ & $9.19930(10)$ & $9.2147(2)$ & $16.5259(2)$ \\
\hline$c, \AA$ & $8.5741(2)$ & $12.1238(2)$ & $11.6978(3)$ & $6.94220(10)$ \\
\hline$\alpha, \operatorname{deg}$ & $103.1890(10)$ & $80.8420(10)$ & $84.7490(10)$ & 90 \\
\hline$\beta$, deg & $109.2230(10)$ & $81.2310(10)$ & $86.1420(10)$ & $99.9630(10)$ \\
\hline$\gamma$, deg & $108.5740(10)$ & $73.2280(10)$ & $67.1760(10)$ & 90 \\
\hline volume, $\AA^{3}$ & $364.003(14)$ & $806.44(2)$ & $796.65(3)$ & $1635.16(4)$ \\
\hline Z & 1 & 1 & 1 & 4 \\
\hline$\rho_{\text {calc }}, \mathrm{g} \mathrm{cm}^{-3}$ & 1.856 & 2.041 & 2.066 & 1.617 \\
\hline $\mathrm{F}_{000}$ & 203 & 478 & 478 & 812 \\
\hline$\mu(\mathrm{Cu} \mathrm{K \alpha}), \mathrm{mm}^{-1}$ & 8.150 & 10.115 & 10.239 & 4.398 \\
\hline Temp., K & 100 & 100 & 100 & 100 \\
\hline residuals: ${ }^{a} \mathrm{R} ; \mathrm{R}_{\mathrm{w}}$ & $0.0245,0.0639$ & $0.0276,0.0720$ & $0.0248,0.0684$ & $0.0256,0.0713$ \\
\hline goodness of fit & 1.089 & 1.071 & 1.073 & 1.027 \\
\hline peak and hole, $\mathrm{e}^{-3}$ & $0.298,-0.619$ & $0.887,-0.728$ & $0.670,-0.500$ & $0.488,-0.266$ \\
\hline
\end{tabular}

${ }^{\mathrm{a}} \mathrm{R}=R_{1}=\Sigma|| F_{o}|-| F_{c}|| / \Sigma\left|F_{o}\right|$ for observed data only. $R_{\mathrm{w}}=w R_{2}=\left\{\Sigma\left[w\left(F_{o}^{2}-F_{c}^{2}\right)^{2}\right] / \Sigma\left[w\left(F_{o}^{2}\right)^{2}\right]\right\}^{1 / 2}$ for all data. ${ }^{b}$ Flack parameter $=0.466(15)$. 
Table 2. contd.

\begin{tabular}{|c|c|c|c|c|}
\hline & 11 & $12 a$ & $13 a$ & $13 b$ \\
\hline CCDC deposit no. & 1500170 & 1500166 & 1500167 & 1500176 \\
\hline color and habit & green block & blue block & green plate & green plate \\
\hline size, $\mathrm{mm}$ & $0.43 \times 0.20 \times 0.13$ & $0.38 \times 0.23 \times 0.16$ & $0.40 \times 0.15 \times 0.02$ & $0.42 \times 0.27 \times 0.07$ \\
\hline Formula & $\mathrm{C}_{14} \mathrm{H}_{14} \mathrm{CuN}_{4} \mathrm{O}_{2} \mathrm{~S}_{2}$ & $\mathrm{C}_{18} \mathrm{H}_{22} \mathrm{CuN}_{4} \mathrm{O}_{4} \mathrm{~S}_{2}$ & $\mathrm{C}_{16} \mathrm{H}_{14} \mathrm{CuN}_{4} \mathrm{O}_{2} \mathrm{~S}_{2}$ & $\mathrm{C}_{16} \mathrm{H}_{14} \mathrm{CuN}_{4} \mathrm{O}_{2} \mathrm{~S}_{2}$ \\
\hline formula weight & 397.95 & 486.05 & 421.97 & 421.97 \\
\hline space group & $P-1$ & $P-1$ & $P 2_{1} / c$ & Pbca \\
\hline$a, \AA$ & $10.9796(2)$ & $7.4925(2)$ & $5.69760(10)$ & $9.40090(10)$ \\
\hline$b, \AA$ & $11.2667(2)$ & $7.8360(2)$ & $10.7035(2)$ & $16.0371(2)$ \\
\hline$c, \AA$ & $11.5223(2)$ & $10.0967(2)$ & $14.1837(2)$ & $23.9505(3)$ \\
\hline$\alpha, \operatorname{deg}$ & $112.5140(10)$ & $97.6630(10)$ & 90 & 90 \\
\hline$\beta$, deg & $99.2840(10)$ & $95.3230(10)$ & $95.8730(10)$ & 90 \\
\hline$\gamma, \operatorname{deg}$ & $98.4040(10)$ & $109.9180(10)$ & 90 & 90 \\
\hline volume, $\AA^{3}$ & $1265.22(4)$ & $546.24(2)$ & $860.44(3)$ & $3610.85(7)$ \\
\hline Z & 3 & 1 & 2 & 8 \\
\hline$\rho_{\text {calc }}, \mathrm{g} \mathrm{cm}^{-3}$ & 1.567 & 1.478 & 1.629 & 1.552 \\
\hline $\mathrm{F}_{000}$ & 609 & 251 & 430 & 1720 \\
\hline$\mu(\mathrm{Cu} \mathrm{K \alpha}), \mathrm{mm}^{-1}$ & 4.263 & 3.469 & 4.221 & 4.023 \\
\hline Temp., K & 100 & 100 & 100 & 100 \\
\hline residuals: ${ }^{a} \mathrm{R} ; \mathrm{R}_{\mathrm{w}}$ & $0.0299,0.0807$ & $0.0331,0.0874$ & $0.0280,0.0747$ & $0.0263,0.0749$ \\
\hline goodness of fit & 1.027 & 1.062 & 1.033 & 1.051 \\
\hline peak and hole, $\mathrm{e}^{-3}$ & $0.553,-0.321$ & $0.670,-0.691$ & $0.371,-0.203$ & $0.453,-0.254$ \\
\hline
\end{tabular}

${ }^{\mathrm{a}} \mathrm{R}=R_{1}=\Sigma|| F_{o}|-| F_{c}|| / \Sigma\left|F_{o}\right|$ for observed data only. $\mathrm{R}_{\mathrm{w}}=w R_{2}=\left\{\Sigma\left[w\left(F_{o}^{2}-F_{c}^{2}\right)^{2}\right] / \Sigma\left[w\left(F_{o}^{2}\right)^{2}\right]\right\}^{1 / 2}$ for all data. ${ }^{b}$ Flack parameter $=0.466(15)$. 
Table 2. contd.

\begin{tabular}{|c|c|c|c|c|}
\hline & 14 & $15 a$ & 16 & 18 \\
\hline CCDC deposit no. & 1500169 & 1500173 & 1500168 & 1500171 \\
\hline color and habit & blue block & green plate & blue block & brown plate \\
\hline size, $\mathrm{mm}$ & $0.33 \times 0.30 \times 0.20$ & $0.43 \times 0.28 \times 0.02$ & $0.25 \times 0.17 \times 0.13$ & $0.43 \times 0.16 \times 0.11$ \\
\hline Formula & $\mathrm{C}_{16} \mathrm{H}_{16} \mathrm{CuN}_{6} \mathrm{O}_{2} \mathrm{~S}_{2}$ & $\mathrm{C}_{14} \mathrm{H}_{8} \mathrm{CuN}_{6} \mathrm{~S}_{2}$ & $\mathrm{C}_{14} \mathrm{H}_{18} \mathrm{Cu}_{2} \mathrm{~N}_{6} \mathrm{O}_{2} \mathrm{~S}_{2}$ & $\mathrm{C}_{24} \mathrm{H}_{18} \mathrm{CuN}_{4} \mathrm{~S}_{2}$ \\
\hline formula weight & 452.01 & 387.92 & 493.54 & 490.08 \\
\hline space group & $P 2_{1} / n$ & $P-1$ & $P 2_{1} / n$ & $P-1$ \\
\hline$a, \AA$ & $10.0868(2)$ & $8.0172(2)$ & $9.2237(7)$ & $6.92010(10)$ \\
\hline$b, \AA$ & $7.16320(10)$ & $10.3427(2)$ & $11.0826(9)$ & $8.22830(10)$ \\
\hline$c, \AA$ & $13.5654(2)$ & $11.3382(3)$ & $10.0614(8)$ & $10.50610(10)$ \\
\hline$\alpha$, deg & 90 & $112.1150(10)$ & 90 & $78.3790(10)$ \\
\hline$\beta$, deg & $94.8530(10)$ & $97.0190(10)$ & $112.280(4)$ & $80.0260(10)$ \\
\hline$\gamma, \operatorname{deg}$ & 90 & $98.5880(10)$ & 90 & $68.3410(10)$ \\
\hline volume, $\AA^{3}$ & $976.64(3)$ & $844.73(4)$ & $951.72(13)$ & $541.371(12)$ \\
\hline Z & 2 & 2 & 2 & 1 \\
\hline$\rho_{\text {calc }}, \mathrm{g} \mathrm{cm}^{-3}$ & 1.537 & 1.525 & 1.722 & 1.503 \\
\hline $\mathrm{F}_{000}$ & 462 & 390 & 500 & 251 \\
\hline$\mu(\mathrm{Cu} \mathrm{K} \alpha), \mathrm{mm}^{-1}$ & 3.790 & 4.193 & 5.001 & 3.375 \\
\hline Temp., $\mathrm{K}$ & 100 & 100 & 100 & 100 \\
\hline residuals: ${ }^{a} \mathrm{R} ; \mathrm{R}_{\mathrm{w}}$ & $0.0224,0.0599$ & $0.0465,0.1508$ & $0.0353,0.1126$ & $0.0254,0.0683$ \\
\hline goodness of fit & 1.102 & 1.194 & 1.119 & 1.043 \\
\hline peak and hole, $\mathrm{e}^{-3}$ & $0.258,-0.451$ & $0.929,-0.475$ & $0.126,-0.196$ & $0.286,-0.360$ \\
\hline
\end{tabular}

${ }^{\mathrm{a}} \mathrm{R}=R_{1}=\Sigma|| F_{o}|-| F_{c}|| / \Sigma\left|F_{o}\right|$ for observed data only. $\mathrm{R}_{\mathrm{w}}=w R_{2}=\left\{\Sigma\left[w\left(F_{o}^{2}-F_{c}^{2}\right)^{2}\right] / \Sigma\left[w\left(F_{o}^{2}\right)^{2}\right]\right\}^{1 / 2}$ for all data. ${ }^{\mathrm{b}}$ Flack parameter $=0.466(15)$. 
Table 2. contd.

\begin{tabular}{|c|c|c|c|c|}
\hline & 19 & 20 & 21 & 22 \\
\hline CCDC deposit no. & 1500175 & 1500172 & 1500177 & 1500174 \\
\hline color and habit & green blade & green prism & green blade & green plate \\
\hline size, $\mathrm{mm}$ & $0.63 \times 0.12 \times 0.06$ & $0.35 \times 0.09 \times 0.07$ & $0.43 \times 0.19 \times 0.10$ & $0.30 \times 0.23 \times 0.04$ \\
\hline Formula & $\mathrm{C}_{24} \mathrm{H}_{18} \mathrm{CuN}_{4} \mathrm{~S}_{2}$ & $\mathrm{C}_{10} \mathrm{H}_{8} \mathrm{CuN}_{6} \mathrm{~S}_{2}$ & $\mathrm{C}_{14} \mathrm{H}_{8} \mathrm{CuN}_{6} \mathrm{~S}_{2}$ & $\mathrm{C}_{6} \mathrm{H}_{4} \mathrm{CuN}_{4} \mathrm{~S}_{2}$ \\
\hline formula weight & 490.08 & 339.88 & 387.92 & 259.79 \\
\hline space group & $P 2_{1} / c$ & $P 2_{1} / c$ & Pccn & $\mathrm{C} 2 / \mathrm{m}$ \\
\hline$a, \AA$ & $6.01380(10)$ & $5.75330(10)$ & $10.7249(2)$ & $10.62740(10)$ \\
\hline$b, \AA$ & $17.0542(3)$ & $7.9824(2)$ & $11.3597(2)$ & $6.95810(10)$ \\
\hline$c, \AA$ & $10.8052(2)$ & $13.9371(3)$ & $22.3429(5)$ & $5.67600(10)$ \\
\hline$\alpha$, deg & 90 & 90 & 90 & 90 \\
\hline$\beta$, deg & $105.6010(10)$ & $95.3270(10)$ & 90 & $91.7830(10)$ \\
\hline$\gamma, \operatorname{deg}$ & 90 & 90 & 90 & 90 \\
\hline volume, $\AA^{3}$ & $1066.92(4)$ & $637.30(2)$ & 2722.07(9) & $1066.92(4)$ \\
\hline Z & 2 & 2 & 8 & 2 \\
\hline$\rho_{\text {calc }}, \mathrm{g} \mathrm{cm}^{-3}$ & 1.525 & 1.771 & 1.639 & 2.057 \\
\hline $\mathrm{F}_{000}$ & 502 & 342 & 1352 & 258 \\
\hline$\mu(\mathrm{Cu} \mathrm{K} \alpha), \mathrm{mm}^{-1}$ & 3.424 & 5.446 & 5.051 & 7.935 \\
\hline Temp., $\mathrm{K}$ & 100 & 100 & 100 & 100 \\
\hline residuals: ${ }^{a} R ; R_{w}$ & $0.0266,0.0746$ & $0.0246,0.0616$ & $0.0320,0.0984$ & $0.0336,0.0960$ \\
\hline goodness of fit & 1.049 & 1.059 & 1.037 & 1.101 \\
\hline peak and hole, $\mathrm{e}^{-3}$ & $0.296,-0.298$ & $0.350,-0.358$ & $0.465,-0.527$ & $0.645,-0.668$ \\
\hline
\end{tabular}

${ }^{\mathrm{a}} \mathrm{R}=R_{1}=\Sigma|| F_{o}|-| F_{c}|| / \Sigma\left|F_{o}\right|$ for observed data only. $\mathrm{R}_{\mathrm{w}}=w R_{2}=\left\{\Sigma\left[w\left(F_{o}^{2}-F_{c}^{2}\right)^{2}\right] / \Sigma\left[w\left(F_{o}^{2}\right)^{2}\right]\right\}^{1 / 2}$ for all data. 
Table 3. Selected bond lengths $(\AA)$ and angles $\left({ }^{\circ}\right){ }^{a}$

\begin{tabular}{|c|c|c|c|c|c|c|c|c|}
\hline \multirow[b]{2}{*}{ Complex } & \multicolumn{4}{|c|}{ Bond Lengths } & \multicolumn{4}{|c|}{ Bond Angles } \\
\hline & $\mathrm{Cu}-\mathrm{N}_{\mathrm{Py}}$ & $\mathrm{Cu}-\mathrm{N}_{\mathrm{CS}}$ & $\mathrm{Cu} \cdot \mathrm{S}^{\mathrm{b}}$ & Other & $\mathrm{N}-\mathrm{Cu}-\mathrm{N}$ & $\mathrm{N}-\mathrm{C}-\mathrm{S}$ & $\mathrm{Cu}-\mathrm{N}-\mathrm{C}$ & $C u^{\prime}{ }^{\prime} S-C^{b}$ \\
\hline $1 a$ & $\begin{array}{l}2.044(2) \\
2.049(2) \\
2.055(2)\end{array}$ & $\begin{array}{l}1.932(2), \\
1.933(2), \\
1.936(2)\end{array}$ & $\begin{array}{l}2.991(2), \\
3.045(2), \\
3.085(2)\end{array}$ & $\begin{array}{l}3.896{ }^{c}{ }^{d} \\
5.004{ }^{d} \\
5.251{ }^{d}{ }^{d} \\
5.472^{d}\end{array}$ & $\begin{array}{c}89.45- \\
91.06\end{array}$ & $\begin{array}{l}179.1(2), \\
179.1(2), \\
179.2(2)\end{array}$ & $\begin{array}{l}179.1(2), \\
179.1(2), \\
179.3(2)\end{array}$ & $\begin{array}{l}92.18 \\
93.27 \\
93.49\end{array}$ \\
\hline 1b & $1.98(2)$ & $1.94(2)$ & $3.04(2)$ & - & 90.00 & $179.7(14)$ & $173.2(13)$ & 93.28 \\
\hline $2 a$ & $\begin{array}{l}2.050(3) \\
2.056(3)\end{array}$ & $\begin{array}{l}1.932(3) \\
1.950(3)\end{array}$ & - & $\begin{array}{c}2.363(3),{ }^{\mathrm{e}} \\
3.820^{\mathrm{c}}\end{array}$ & $\begin{array}{c}89.45(12)- \\
90.25(12)\end{array}$ & $\begin{array}{l}178.6(3) \\
179.2(3)\end{array}$ & $\begin{array}{l}\text { 168.2(3) } \\
160.6(3)\end{array}$ & - \\
\hline $2 b$ & $\begin{array}{l}2.02(1) \\
2.02(1) \\
2.06(1)\end{array}$ & $\begin{array}{l}1.94(1), \\
1.94(1), \\
1.95(1), \\
1.96(1)\end{array}$ & $\begin{array}{c}3.043(5), \\
3.049(6), \\
(3.263(5)), \\
(3.270(5))\end{array}$ & - & $\begin{array}{c}89.00- \\
91.00\end{array}$ & $\begin{array}{l}176.7(16), \\
178.1(16), \\
178.4(15), \\
178.7(15)\end{array}$ & $\begin{array}{l}\text { 162.2(15), } \\
\text { 168.2(19), } \\
\text { 171.9(13), } \\
\text { 173.7(13), }\end{array}$ & $\begin{array}{c}95.46 \\
98.36 \\
(113.20) \\
(115.42)\end{array}$ \\
\hline 3 & $2.0140(17)$ & $1.9598(19)$ & $(3.3869(7))$ & $3.528^{c}$ & $\begin{array}{l}89.34(7) \\
90.66(7)\end{array}$ & $178.4(2)$ & $163.8(2)$ & (109.40) \\
\hline 4 & $\begin{array}{l}2.016(3), \\
2.017(3), \\
2.020(3), \\
2.033(3), \\
2.057(3), \\
2.060(3)\end{array}$ & $\begin{array}{l}1.947(3), \\
1.948(3), \\
1.952(3), \\
1.956(3), \\
1.960(3), \\
1.963(3)\end{array}$ & $\begin{array}{l}2.9098(11) \\
2.9137(11) \\
2.9413(10) \\
2.9864(11) \\
3.0971(11) \\
3.1475(11)\end{array}$ & $\begin{array}{l}5.039,^{d} \\
5.004{ }^{d}{ }^{d} \\
5.269{ }^{d} \\
5.289,^{d} \\
5.852^{d}\end{array}$ & $\begin{array}{c}87.24(13)- \\
91.85(13)\end{array}$ & $\begin{array}{l}178.0(3), \\
178.8(4), \\
179.1(3), \\
179.3(4), \\
179.6(4), \\
179.7(4)\end{array}$ & $\begin{array}{l}155.5(3), \\
160.5(3), \\
167.1(3), \\
167.3(3), \\
168.8(3), \\
170.9(3)\end{array}$ & $\begin{array}{c}89.63 \\
95.59 \\
96.37 \\
97.03 \\
104.84 \\
109.05\end{array}$ \\
\hline 5 & $2.0512(15)$ & $1.9359(16)$ & $3.1611(5)$ & $\begin{array}{l}3.702)^{c} \\
5.023^{d}\end{array}$ & $\begin{array}{l}89.72(6), \\
90.28(6)\end{array}$ & $178.71(16)$ & $172.05(15)$ & 97.21 \\
\hline 6 & $2.0171(15)$ & $1.9610(16)$ & 3.201 & $3.387^{c}$ & $\begin{array}{l}89.30(6) \\
90.70(6)\end{array}$ & $178.19(17)$ & $161.70(15)$ & $(108.77)$ \\
\hline 7 & $\begin{array}{c}2.032(2) \\
2.057(2)\end{array}$ & $\begin{array}{c}1.942(2){ }^{f} \\
1.947(2)\end{array}$ & $\begin{array}{c}(5.253){ }_{,}^{f} \\
2.6868(7)\end{array}$ & $\begin{array}{l}3.1366^{\mathrm{g}} \\
5.509^{\mathrm{d}}\end{array}$ & $\begin{array}{c}88.14(10)- \\
91.78(10)\end{array}$ & $\begin{array}{c}178.9(3){ }^{f} \\
179.0(3)\end{array}$ & $\begin{array}{c}155.0(2){ }^{f} \\
169.4(2)\end{array}$ & $\begin{array}{l}(88.76),{ }^{f} \\
96.16(9)\end{array}$ \\
\hline 8 & $\begin{array}{l}2.053(2) \\
2.060(2)\end{array}$ & $\begin{array}{l}1.924(2),{ }^{f} \\
1.942(2)\end{array}$ & $\begin{array}{c}(3.4877(8)){ }^{f} \\
2.8696(7)\end{array}$ & $\begin{array}{l}5.606^{d} \\
5.635^{d}\end{array}$ & $\begin{array}{l}89.22(9)- \\
90.91(9)\end{array}$ & $\begin{array}{c}178.9(2),{ }^{f} \\
178.6(2)\end{array}$ & $\begin{array}{c}169.8(2),{ }^{f} \\
170.8(2)\end{array}$ & $\begin{array}{c}(94.52){ }^{f} \\
93.99\end{array}$ \\
\hline 9 & $\begin{array}{l}2.041 \\
2.050\end{array}$ & $1.952,1.966$ & $2.992,3.067$ & - & $\begin{array}{c}89.27- \\
90.73\end{array}$ & $\begin{array}{l}178.47 \\
178.77\end{array}$ & $\begin{array}{l}160.09 \\
170.25\end{array}$ & $\begin{array}{l}96.85 \\
97.34\end{array}$ \\
\hline 10 & $2.0343(16)$ & $\begin{array}{c}1.933(2),{ }^{f} \\
1.954(2)\end{array}$ & $\begin{array}{c}(4.372){ }^{f} \\
2.7637(8)\end{array}$ & $3.697^{c}$ & $\begin{array}{l}89.53(4) \\
89.75(4)\end{array}$ & $\begin{array}{c}179.8(3),{ }^{f} \\
178.0(2)\end{array}$ & $\begin{array}{c}173.2(2){ }^{f} \\
166.1(2)\end{array}$ & $\begin{array}{c}(52.38),{ }^{f} \\
100.15(9)\end{array}$ \\
\hline 11 & $\begin{array}{c}2.017(5),{ }^{\mathrm{h}} \\
2.0288(15), \\
2.0373(15)\end{array}$ & $\begin{array}{c}1.9538(15), \\
1.9722(16){ }^{h} \\
2.026(5)^{\mathrm{h}}\end{array}$ & $\begin{array}{l}2.9249(4), \\
2.9991(4) \\
3.1051(4)\end{array}$ & $\begin{array}{l}3.688^{c}{ }^{c} \\
4.927^{d}\end{array}$ & $\begin{array}{c}86.00(13)- \\
94.00(13)\end{array}$ & $\begin{array}{c}173.5(6),{ }^{h} \\
178.61(18), \\
179.61(18)\end{array}$ & $\begin{array}{c}159.6(5),{ }^{\mathrm{h}} \\
162.41(14), \\
168.54(15)\end{array}$ & $\begin{array}{l}98.12, \\
98.46, \\
100.37\end{array}$ \\
\hline $12 a$ & $2.0346(18)$ & $1.9694(19)$ & - & $2.4222(16)^{\mathrm{e}}$ & $\begin{array}{l}89.91(7) \\
90.09(7)\end{array}$ & $179.2(2)$ & $168.49(18)$ & - \\
\hline
\end{tabular}




\begin{tabular}{|c|c|c|c|c|c|c|c|c|}
\hline $12 b$ & $\begin{array}{l}2.048(2) \\
2.035(2)\end{array}$ & $\begin{array}{l}1.930(3){ }^{f} \\
1.930(3), \\
1.940(3), \\
1.940(4)\end{array}$ & $\begin{array}{l}(4.119),^{f} \\
2.863(1), \\
2.942(1)\end{array}$ & $3.782^{c}$ & $\begin{array}{c}88.27(6)- \\
91.52(6)\end{array}$ & $\begin{array}{l}179.24{ }^{f} \\
178.23, \\
178.74, \\
179.69^{f}\end{array}$ & $\begin{array}{l}169.61{ }^{f} \\
166.61, \\
167.74, \\
171.75^{f}\end{array}$ & $\begin{array}{c}(58.50){ }^{f} \\
98.25(12) \\
\text { ' } \\
99.36(13)\end{array}$ \\
\hline $13 a$ & $2.0617(17)$ & $1.9299(17)$ & $3.0834(5)$ & $3.785^{i}$ & $\begin{array}{l}88.87(7) \\
91.13(7)\end{array}$ & $178.53(19)$ & 169.81(17) & 93.89 \\
\hline $13 b$ & $\begin{array}{l}2.0387(14), \\
2.0474(14)\end{array}$ & $\begin{array}{l}1.9506(15), \\
1.9565(15)\end{array}$ & $\begin{array}{l}2.8258(5) \\
3.0460(5)\end{array}$ & $5.347^{d}$ & $\begin{array}{c}87.51(6)- \\
92.03(6)\end{array}$ & $\begin{array}{l}\text { 178.69(16), } \\
179.19(16)\end{array}$ & $\begin{array}{l}168.16(14), \\
171.25(14)\end{array}$ & $\begin{array}{l}94.66 \\
95.92\end{array}$ \\
\hline 14 & $2.0483(13)$ & $1.9664(13)$ & - & $2.4221(11)^{\mathrm{e}}$ & $\begin{array}{l}89.18(5) \\
90.82(5)\end{array}$ & $178.54(14)$ & $173.96(12)$ & - \\
\hline $15 a$ & $\begin{array}{l}2.050(4) \\
2.058(4)\end{array}$ & $\begin{array}{l}1.946(4), \\
1.947(4)\end{array}$ & $\begin{array}{l}2.9314(13) \\
2.9522(12)\end{array}$ & $\begin{array}{l}5.668^{d} \\
5.685^{d}\end{array}$ & $\begin{array}{c}90.36(14)- \\
89.81(14)\end{array}$ & $\begin{array}{l}179.1(4) \\
178.9(4)\end{array}$ & $\begin{array}{l}171.5(3) \\
166.7(3)\end{array}$ & $\begin{array}{l}95.20 \\
96.46\end{array}$ \\
\hline $15 b$ & $2.0552(18)$ & $1.9364(19)$ & $\begin{array}{c}2.9529(7) \\
3.002\end{array}$ & $5.679^{d}$ & $\begin{array}{c}89.63- \\
90.37\end{array}$ & $\begin{array}{l}179.1(2) \\
179.6(2)\end{array}$ & $\begin{array}{c}168.59 \\
171.60(18)\end{array}$ & $\begin{array}{l}96.54 \\
96.75\end{array}$ \\
\hline 16 & $1.997(3)$ & $1.932(3)$ & $2.8484(10)$ & $\begin{array}{c}1.922(2),^{e} \\
3.0241(10){ }^{j} \\
3.561^{i}\end{array}$ & $93.03(12)$ & $178.5(3)$ & $174.5(3)$ & 101.96 \\
\hline 17 & $\begin{array}{l}2.021(2) \\
2.023(2)\end{array}$ & $\begin{array}{l}1.943(3) \\
1.954(3)\end{array}$ & $\begin{array}{c}2.867(1) \\
(3.508)\end{array}$ & $\begin{array}{l}4.9488^{d} \\
5.350^{d}\end{array}$ & $\begin{array}{c}88.88- \\
90.82\end{array}$ & $\begin{array}{l}178.8(3) \\
179.0(3)\end{array}$ & $\begin{array}{c}167.38 \\
167.53\end{array}$ & $\begin{array}{l}93.35 \\
(79.39)\end{array}$ \\
\hline 18 & $2.0241(13)$ & $1.9267(14)$ & $(4.816)^{f}$ & $4.062^{c}$ & $\begin{array}{l}90.69(5) \\
89.31(5)\end{array}$ & $179.10(15)^{f}$ & $171.28(14)^{f}$ & $(116.66)^{f}$ \\
\hline 19 & $2.0319(15)$ & $1.9442(16)$ & $(3.2499(5))^{f}$ & $5.366^{d}$ & $\begin{array}{l}89.52(6) \\
90.48(6)\end{array}$ & $179.57(18)^{f}$ & $168.62(15)^{f}$ & $(97.14)^{f}$ \\
\hline 20 & $2.0492(17)$ & $1.9381(17)$ & $3.0254(5)$ & $5.647^{d}$ & $\begin{array}{l}89.66(7) \\
90.34(7)\end{array}$ & $178.76(18)$ & $166.39(17)$ & 95.69 \\
\hline 21 & $\begin{array}{l}2.037(3), \\
2.062(3), \\
2.034(3), \\
2.067(3)\end{array}$ & $\begin{array}{l}1.938(2) \\
1.938(2)\end{array}$ & $\begin{array}{l}2.9947(6) \\
2.9952(6)\end{array}$ & $5.682^{d}$ & $\begin{array}{c}89.59(6)- \\
90.41(6)\end{array}$ & $\begin{array}{l}178.8(2) \\
179.4(2)\end{array}$ & $\begin{array}{l}170.2(2) \\
173.4(2)\end{array}$ & $\begin{array}{l}93.95 \\
94.47\end{array}$ \\
\hline 22 & $2.084(3)$ & $1.924(3)$ & $2.9418(7)$ & - & 90.0 & 179.1(3) & $174.7(3)$ & 95.37 \\
\hline 23 & $2.022(3)$ & $\begin{array}{l}1.956(5) \\
1.972(5)\end{array}$ & $2.676(2)$ & $\begin{array}{l}5.0566^{d} \\
5.443^{d}\end{array}$ & $\begin{array}{l}88.83(7) \\
89.99(8)\end{array}$ & $179.8(6)$ & $\begin{array}{l}154.42 \\
170.06\end{array}$ & 94.79 \\
\hline 24 & $2.044(1)$ & $1.950(1)$ & $2.9498(4)$ & $5.343^{d}$ & $\begin{array}{l}89.51(5) \\
90.49(5)\end{array}$ & $179.1(1)$ & 159.33 & 102.00 \\
\hline 25 & $2.016(2)$ & $1.958(2)$ & - & $2.4346(19)^{\mathrm{e}}$ & $\begin{array}{l}\text { 87.93(9), } \\
92.07(9)\end{array}$ & 178.77 & $162.7(2)$ & - \\
\hline 26 & $\begin{array}{l}2.047(3) \\
2.066(3)\end{array}$ & $\begin{array}{c}1.929(3),^{f} \\
1.928(3)\end{array}$ & $\begin{array}{c}(3.229))^{f} \\
2.938\end{array}$ & $5.614^{d}$ & $\begin{array}{c}89.38(13)- \\
91.17(12)\end{array}$ & $\begin{array}{c}178.5(3),^{f} \\
179.7(4)\end{array}$ & $\begin{array}{c}166.9(3){ }^{f} \\
163.8(3)\end{array}$ & $\begin{array}{c}(88.42))^{f} \\
92.52\end{array}$ \\
\hline 27 & 2.053 & 1.957 & - & $2.430^{\mathrm{e}}$ & $\begin{array}{l}89.53 \\
90.47\end{array}$ & 177.98 & 163.14 & - \\
\hline
\end{tabular}


a esd values provided when available. ${ }^{b}$ Values in parenthesis for non-bonding $\mathrm{Cu}$ "'S. ${ }^{\mathrm{c}}$ Centroid"'centroid (face-to-face $\pi$-stack). ${ }^{d}$ Centroid'“centroid (edge-to-face $\pi$-stack). ${ }^{\mathrm{e}} \mathrm{Cu}-\mathrm{O}$. ${ }^{\mathrm{f}} \mathrm{Terminal} \mathrm{CuNCS} .{ }^{\mathrm{g}} \mathrm{Cu}-\mathrm{Br}$. ${ }^{\mathrm{h}}$ Major position in disordered structure. ${ }^{\mathrm{i}} \mathrm{C}_{\mathrm{Me}}$..'centroid. ${ }^{\mathrm{j}} \mathrm{Cu} \cdot \mathrm{Cu}$. 
Table 4. IR Data.

\begin{tabular}{|c|c|c|c|c|}
\hline Complex & Ligand & $v_{\mathrm{CN}}\left(\mathrm{cm}^{-1}\right)$ & $v_{\mathrm{SC}}\left(\mathrm{cm}^{-1}\right)$ & Other $\left(\mathrm{cm}^{-1}\right)$ \\
\hline $1 a$ & Py & 2087 & 823 & - \\
\hline $2 a$ & 2-MePy & 2087 & $777^{\mathrm{a}}$ & $3383^{b}$ \\
\hline 3 & 3-MePy & 2079 & 806 & - \\
\hline 4 & 4-MePy & 2081 & 832 & - \\
\hline 5 & 3-FPy & 2087 & 844 & - \\
\hline 6 & 3-ClPy & 2073 & $816^{a}$ & - \\
\hline 8 & 3-BrPy & 2087 & 829 & - \\
\hline 10 & 3-MeOPy & 2104,2071 & 818 & - \\
\hline 11 & 4-MeOPy & 2081 & 844 & - \\
\hline $12 a$ & 3-AcPy & 2126,2062 & $825^{a}$ & $1690^{c, d}$ \\
\hline $13 a / 13 b$ & 4-AcPy & 2097 & $825^{a}$ & $1694^{c}$ \\
\hline 14 & 3-NCPy & 2097 & 828 & $3472^{b}, 2243^{e}$ \\
\hline $15 a$ & 4-NCPy & 2091 & 867 & $2244^{e}$ \\
\hline 16 & 2- $\mathrm{NH}_{2} \mathrm{Py}$ & 2095 & 819 & $3439,3312,3198^{f}$ \\
\hline 17 & 4- $\mathrm{NH}_{2} \mathrm{Py}$ & 2127,2073 & $850^{\mathrm{a}}$ & $3460,3341,3213^{f}$ \\
\hline 18 & 2-PhPy & 2089 & 760 & - \\
\hline 19 & 3-PhPy & 2081 & 769 & - \\
\hline 20 & $\mathrm{Pdz}$ & 2114,2073 & 810 & - \\
\hline 21 & Bpy & 2089 & 813 & - \\
\hline 22 & Pyz & 2129,2058 & 828 & - \\
\hline
\end{tabular}

${ }^{\mathrm{a}}$ Band partially obscured. ${ }^{\mathrm{b}} \mathrm{MeOH}$ band. ${ }^{\mathrm{C}} \mathrm{C}=\mathrm{O}$ band. ${ }^{\mathrm{d}} \mathrm{MeOH}$ band not observed ${ }^{\mathrm{e}} \mathrm{RC} \equiv \mathrm{N}$ band. ${ }^{\mathrm{f}} \mathrm{NH}_{2}$ bands. 
Table 5. trans-[Cu(NCS $\left.)_{2}(\mathrm{XPy})_{2}\right]$ Complexes Sorted by Structural Category.

\begin{tabular}{|c|c|c|c|c|c|c|}
\hline $\mathrm{D}_{4 \mathrm{~h}}$ Chains & $\begin{array}{c}D_{4 h} \\
\text { Networks }\end{array}$ & $\begin{array}{c}\mathrm{D}_{4 \mathrm{~h}} \\
\text { Monomers }\end{array}$ & $\mathrm{C}_{4 \mathrm{v}}$ Dimers & $\mathrm{C}_{4 v}$ Chains & $\begin{array}{c}\mathrm{O}_{\mathrm{h}} \text { Monomers } \\
(\cdot 2 \mathrm{MeOH})\end{array}$ & $\begin{array}{c}\mathrm{C}_{4 \mathrm{v}} \text { Monomers } \\
(\bullet \mathrm{MeOH})\end{array}$ \\
\hline $\begin{array}{c}\operatorname{Py}(1 \mathbf{a}, 1 \mathbf{b}){ }^{a} \\
\text { 3-FPy (5), } \\
\text { 3-CIPy (6), } \\
\text { 4-BrPy (9), } \\
\text { 4-AcPy } \\
(13 a), \\
\text { 4-NCPy } \\
(15 a, 15 b){ }^{a} \\
\text { 4-PhCOPy } \\
(26) \\
\text { Pdz (20) }\end{array}$ & $\begin{array}{c}\text { 2-MePy } \\
(\mathbf{2 b}),{ }^{,} \\
\text {4-MePy (4), } \\
\text { 4-MeOPy } \\
(\mathbf{1 1}), \\
\text { 4-AcPy } \\
(\mathbf{1 3 b}),{ }^{b} \\
\text { 4- } \mathrm{NH}_{2} \mathrm{COPy} \\
\text { (24) }\end{array}$ & $\begin{array}{l}\text { 3-MePy (3), } \\
\text { 2-PhPy (18), } \\
\text { 3-PhPy (19) }\end{array}$ & $\begin{array}{c}\text { 2/3-BrPy (7) } \\
\text { 3-BrPy (8), } \\
\text { 3-MeOPy } \\
(10) \\
\text { 3-AcPy } \\
(12 b)^{b}\end{array}$ & $\begin{array}{c}\text { 4- } \mathrm{NH}_{2} \mathrm{Py} \\
(\mathbf{1 7}), \\
\text { 4-MeHNPy } \\
\text { (23) }\end{array}$ & $\begin{array}{c}\text { 3-NCPy (14), } \\
\text { 3-AcPy (12a), } \\
\text { 3-(2-MeO- } \\
\text { PhCH=NPy) } \\
\text { (27) }\end{array}$ & 2-MePy $(2 a)^{b}$ \\
\hline
\end{tabular}

${ }^{a}$ Single entry represents two polymorphs with similar structures. ${ }^{b}$ Polymorphs or solvates having different structures. 
Structural Comparison of Copper(II) Thiocyanate Pyridine Complexes.

Joseph V. Handy, Gerardo Ayala, and Robert D. Pike*

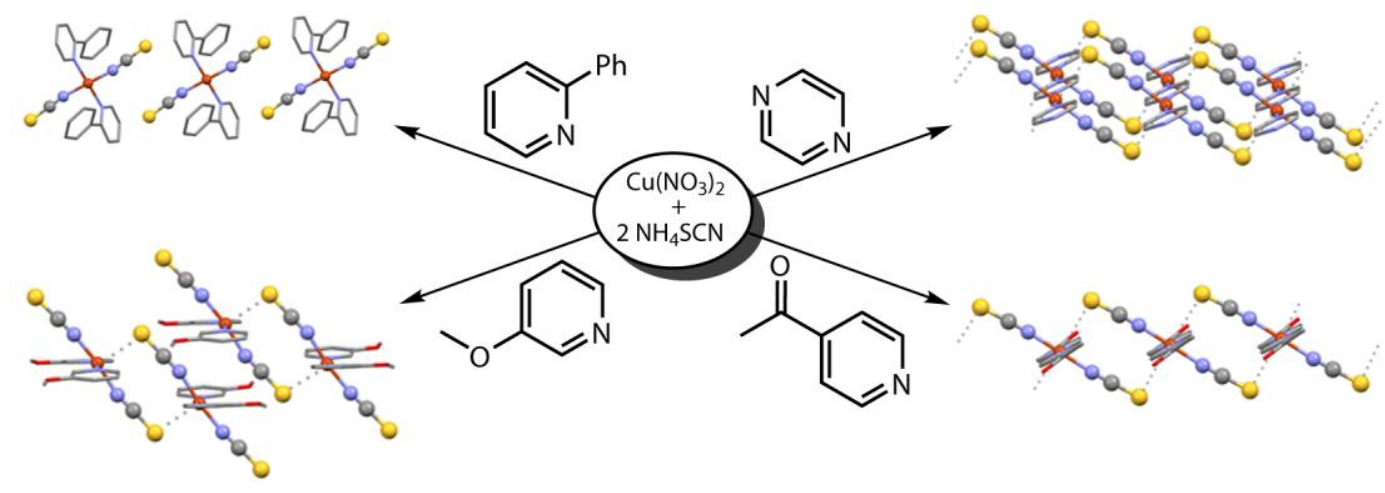

Graphical Abstract:

Copper(II) thiocyanate forms square planar complexes with substituted pyridines (XPy), trans-[Cu(NCS $\left.)_{2}(\mathrm{XPy})_{2}\right]$. Thiocyanate is primarily $\mathrm{N}$-bonded, occasionally producing monomers. But in most cases thiocyanate bridging via long $\mathrm{Cu}$ "'S bonds produces dimers, chains or sheets. Pyridine substituent positions influence the degree of bonding. Bridging ligands $L=4,4^{\prime}$-dipyridyl and pyrazine produce $\left[\mathrm{Cu}(\mathrm{NCS})_{2}(\mathrm{LL})\right]$. 